INVITED REVIEW

\title{
New perspectives for gene therapy in endocrinology
}

\author{
Luisa Barzon, Roberta Bonaguro ${ }^{1}$, Giorgio Palù ${ }^{1}$ and Marco Boscaro \\ Department of Medical and Surgical Sciences and ${ }^{1}$ Department of Histology, Microbiology and Medical Biotechnologies, University of Padova, \\ Padova, Italy \\ (Correspondence should be addressed to M Boscaro, Department of Medical and Surgical Sciences, University of Padova, Via Ospedale, 105 , \\ 35128 Padova, Italy; Email: mboscaro@ux1.unipd.it, or to G Palù, Department of Histology, Microbiology and Medical Biotechnologies, \\ University of Padova, Via A Gabelli, 63, 35121 Padova, Italy; Email: gpalu@ux1.unipd.it)
}

\begin{abstract}
Gene therapy for endocrine diseases represents an exciting new type of molecular intervention that may be a curative one. Endocrine disorders that might be treated by gene therapy include monogenic diseases, such as GH deficiency and hypothalamic diabetes insipidus, and multifactorial diseases, such as diabetes mellitus, obesity and cancer. Premises seem promising for endocrine tumours, but many combined approaches of cell and gene therapy are foreseeable also for other endocrine disorders. This review outlines the principles of gene therapy, describes the endocrine disorders that might take advantage of gene transfer approaches, as well as the gene therapy interventions that have already been attempted, their major limitations and the problems that remain to be solved.
\end{abstract}

European Journal of Endocrinology 143 447-466

\section{Introduction}

In the last three decades scientific progress in biomedical research has revealed the molecular mechanisms and genetic bases of many human diseases. The observation that some pathologies are caused by the inheritance of a single, functionally defective gene (monogenic diseases) generated the concept of gene-based therapy consisting of the supplementation of the defective gene with a functional one to be transferred to the affected cells.

Gene therapy, in its initial and broadest sense, can be defined as the transfer of a gene to a patient for therapeutic purposes. Initially developed as a strategy to treat inherited monogenic disorders by supplying the correct, wild-type copy of a mutated gene, gene therapy has gained importance as a tool to treat a growing number of human diseases. Indeed, the original concept of gene therapy as 'gene supplementation' has rapidly switched to the more general one of any strategy that employs genetic material (DNA or RNA) to prevent or cure a variety of diseases, many of which do not involve germ-line mutations, including multifactorial and somatic genetic diseases, such as diabetes mellitus, obesity, hypertension and cancer.

The development of more sophisticated techniques of molecular biology has allowed us to go rapidly from theory to application, as demonstrated by the 396 gene therapy clinical trials, involving 3278 patients worldwide, which have been undertaken since the first one in 1989 (data from Journal of Gene Medicine, www. wiley.co.uk/genmed, updated to 1 September 1999) (1).

Even though the disorders targeted by gene therapy approaches span the entire spectrum of human diseases, as shown in Table 1 cancer has become a major interest, with $63.6 \%$ of the ongoing protocols involving cancer patients (1).

Notwithstanding the disappointing preliminary clinical results, gene therapy has become an established concept in medicine. The future success of gene therapy relies on the progress of the basic science, in the discovery of new disease-related genes, and in the development of suitable animal models of human diseases.

As for endocrine diseases, gene therapy is still at an experimental stage, since no clinical studies have been published so far. However, significant advances have been made during the last few years, and in vitro and in vivo studies suggest that several endocrine diseases could benefit from gene therapy.

\section{Perspectives for gene therapy in endocrinology}

\section{Gene therapy strategies for endocrine diseases}

Endocrine diseases can be divided into six broad categories, including subnormal hormone production, hormone overproduction, production of abnormal hormones, resistance to hormone action, abnormalities 
Table 1 Update of gene therapy clinical trials.

\begin{tabular}{lrrrrrr}
\hline & \multicolumn{2}{c}{ Protocols } & & \multicolumn{2}{c}{ Patients } \\
\cline { 2 - 3 } \cline { 6 - 6 } & Number & $\%$ & & Number & $\%$ \\
\hline Cancer & 252 & 63.6 & & 2269 & 69.2 \\
Monogenic diseases & 53 & 13.4 & & 298 & 9.1 \\
Gene marking & 41 & 10.4 & & 227 & 6.9 \\
Infectious diseases & 33 & 8.3 & & 412 & 12.6 \\
Healthy volunteers & 2 & 0.5 & & 6 & 0.2 \\
Other & 15 & 3.8 & & 66 & 2 \\
Total & 396 & 100 & & 3278 & 100 \\
\hline
\end{tabular}

of hormone transport or metabolism, and multiple hormone abnormalities, including endocrine tumours (2). These disorders can result in either endocrine hyperfunction or hypofunction. Research progress in endocrinology has allowed the identification of inherited and acquired genetic disorders, as well as the molecular bases of many endocrine diseases, opening the possibility of correcting the underlying defect. Indeed, conventional treatments of most human disorders are often focused at improving symptoms, rather than at correcting the causative defects. Notwithstanding the success of current conventional therapy, the question arises as to whether there is a true need for gene therapy of endocrine diseases. A first answer could be that, in many cases, current therapeutic approaches cannot truly cure the patient, and that hormone replacement cannot always reproduce physiological hormone levels. Moreover, gene therapy may provide useful tools for the treatment of endocrine tumours and of immune-based endocrine disorders which do not respond to conventional treatments.

Different approaches of genetic intervention are foreseeable for endocrine diseases, as summarised in Fig. 1. Strategies for gene therapy of endocrine hyperfunction require either the transfer of a gene with ameliorating effects, such as tyrosine hydroxylase in prolactinomas (3), or the inhibition of genes associated with hormone hypersecretion, by the use of antisense oligonucleotides or ribozymes. Endocrine hypofunction may require the delivery of the wild-type gene coding for the lacking hormone, such as the growth hormone $(\mathrm{GH})$ gene in $\mathrm{GH}$ deficiency. Immunomodulating gene therapy could be useful in the treatment of autoimmune diseases that result in either endocrine hyperfunction or hypofunction. Benign and malignant endocrine tumours would take advantage of tumour suppressor gene delivery, oncogene inhibition, anti-angiogenic approaches or suicide and immunomodulating gene therapy.

\section{Methods of gene transfer}

Gene therapy requires efficient delivery of nucleic acid sequences to target cells, adequate and prolonged expression of the introduced gene, without any toxic side-effects for the target tissue and for the individual as a whole. Ex vivo and in vivo approaches have been used. Ex vivo strategies require the removal of cells from the body, their transduction by viral or non-viral vectors carrying the therapeutic gene, and their reinfusion into the patient. The ex vivo approach has the advantage that safety of modified cells can be evaluated before their administration to the patient. However, isolation of a sufficient number of cells and their appropriate manipulation in culture without causing undesirable changes in their biological properties are required. In the in vivo approach the vector carrying the therapeutic gene is directly administered to the patient.

Given the identification and availability of a large number of therapeutic sequences, the limiting step for a successful gene therapy is the development of an efficient gene transfer system to reach the target cells. With few exceptions, such as the skeletal muscle and the skin, naked DNA is not efficiently taken up

\section{$\begin{gathered}\text { endocrine } \\ \text { hyperfunction }\end{gathered}$
$\begin{aligned} & \text {-gene supplementation } \\ & \text {-antisense oligonucleotides }\end{aligned}$
-ribozymes
endocrine
diseases}

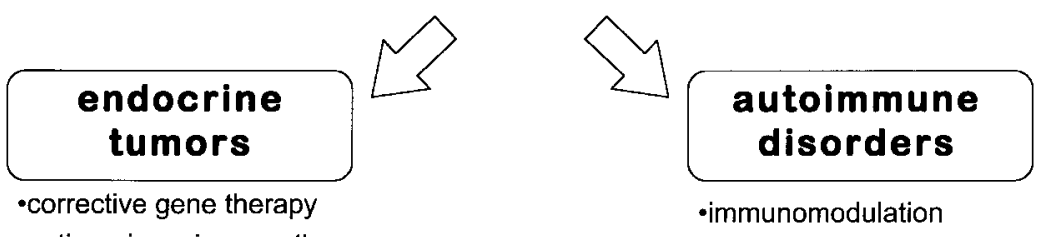

-anti-angiogenic gene therapy

-suicide gene therapy

-immunotherapy

Figure 1 Gene therapy approaches for endocrine diseases. 
Table 2 Main features of the most commonly used vector systems.

\begin{tabular}{|c|c|c|c|c|c|c|}
\hline & Retrovirus & Adenovirus & HSV & AAV & Liposomes & Naked DNA \\
\hline Insert size & $8 \mathrm{~kb}$ & $35 \mathrm{~kb}$ & $>20 \mathrm{~kb}$ & $<4 \mathrm{~kb}$ & $>20 \mathrm{~kb}$ & $>20 \mathrm{~kb}$ \\
\hline Functional titre (cfu/ml) & $10^{7}$ & $10^{11}$ & $10^{10}$ & $10^{9}$ & Not defined & Not defined \\
\hline Integration & Yes & No & No & Unsure & No & No \\
\hline Sustained expression & Variable & Transient & Transient & Variable & Transient & Transient \\
\hline In vivo delivery & Poor & High & High & High & Variable & Muscular tissue \\
\hline Quiescent cells & Only lentivirus & Yes & Yes & Yes & Yes & Yes \\
\hline
\end{tabular}

and expressed by mammalian cells. For this reason it is necessary to design suitable vectors for gene transfer and gene expression. Most vectors presently in use are based upon viruses, such as retroviruses, adenoviruses, adeno-associated viruses (AAVs) and herpes viruses.

The wild-type virus is genetically modified to be unable to replicate and to be non-pathogenic, while retaining infectivity. Each viral vector presents advantages and disadvantages; as a group, viral vectors still cause much concern about safety. Non-viral vectors, such as liposomes and molecular conjugates, partially overcome this last issue, but remain much less efficient than viral vectors (Table 2).

The choice of a vector is dependent upon the target cell. In gene therapy approaches for rapidly proliferating cells, such as cancer cells, retroviral vectors are the most indicated, since they only infect dividing cells. If the target cells are quiescent, adenoviral and AAV vectors are the most suitable ones, since they infect both dividing and non-dividing cells. Another factor to be considered in choosing a vector is the size of the therapeutic gene that has to be transferred. Adenoviral vectors can accommodate up to $30 \mathrm{~kb}$ of foreign genes, whereas AAV vectors no more than $4.5 \mathrm{~kb}$. Retroviral vectors have a gene transfer capacity of about $7-8 \mathrm{~kb}$.

When a long-term expression of the therapeutic cassette is required, retroviral vectors are the most appealing ones, since they integrate into the host genome, assuring a quite stable expression. On the contrary, with adenoviral vectors, whose genome is carried extra-chromosomally, repeated administrations are necessary to obtain a sustained expression. The immune response against adenoviral vectors, which is driven by the expression of viral proteins, and the need for repeated administrations, can be deleterious in those cases when stable transgene expression is required; in some others, as in cancer gene therapy, it may prove useful, helping in tumour recognition and killing.

A major limitation of the gene transfer systems so far developed is the difficulty in obtaining clinically relevant levels of gene expression. Moreover, no single vector has emerged as being optimal for all applications. Current systems differ in their suitability for ex vivo versus in vivo adoption, their capability for persistent gene expression, and for the induction of toxicity. Each of the different vector systems presents advantages and disadvantages, which depend also on the disease that has to be treated. An ideal vector containing all the possible components to overcome the barriers to gene delivery is depicted in Fig. 2 .

\section{Targeted gene therapy in endocrinology}

An important issue in the development of gene therapy protocols is the need to target therapeutic gene delivery. Indeed, safety is a primary concern of gene therapy, and targeted vectors are required both to minimise the risk of germ-line cell transduction and to prevent sideeffects to the surrounding healthy tissues. Moreover, targeting can reduce vector wastage, and the amount of vector stocks that need to be produced and administered in vivo in order to achieve therapeutic levels of transduction.

Targeting of vectors can be obtained in many ways. The easiest one is to deliver the vector directly at the target site. For systemic administration molecular engineering is required to target either gene expression or gene delivery. A transcriptional targeting can be attempted by the introduction of tissue-specific or tumour-specific enhancers/promoters to control the expression of the therapeutic genes. Targeted gene delivery may be achieved also by the exploitation of the natural tropism shown by some viruses for specific tissues (e.g. hepatitis virus for liver cells), or by modification of the viral tropism (viral envelope pseudotyping; expression of antibodies or ligands on the viral particle surface to confer new binding specificity towards target cell receptors).

Endocrine glands appear to favour targeted gene therapy at different levels: (i) the easily accessible anatomical site of some endocrine glands (thyroid, pituitary) allows the direct inoculation of the vector, and the evaluation of cell transduction; and (ii) transcriptional control elements (enhacer/promoter) for the expression of tissue-specific genes (hormones, hormone receptors) may be employed to selectively direct transgene expression (Table 3); and (iii) tissue-specific surface proteins (such as hormone receptors) may be used as targets for vectors with modified tropism.

\section{Targeted gene correction in endocrinology}

Gene therapy has been traditionally conceived as 'gene supplementation', an approach in which the 


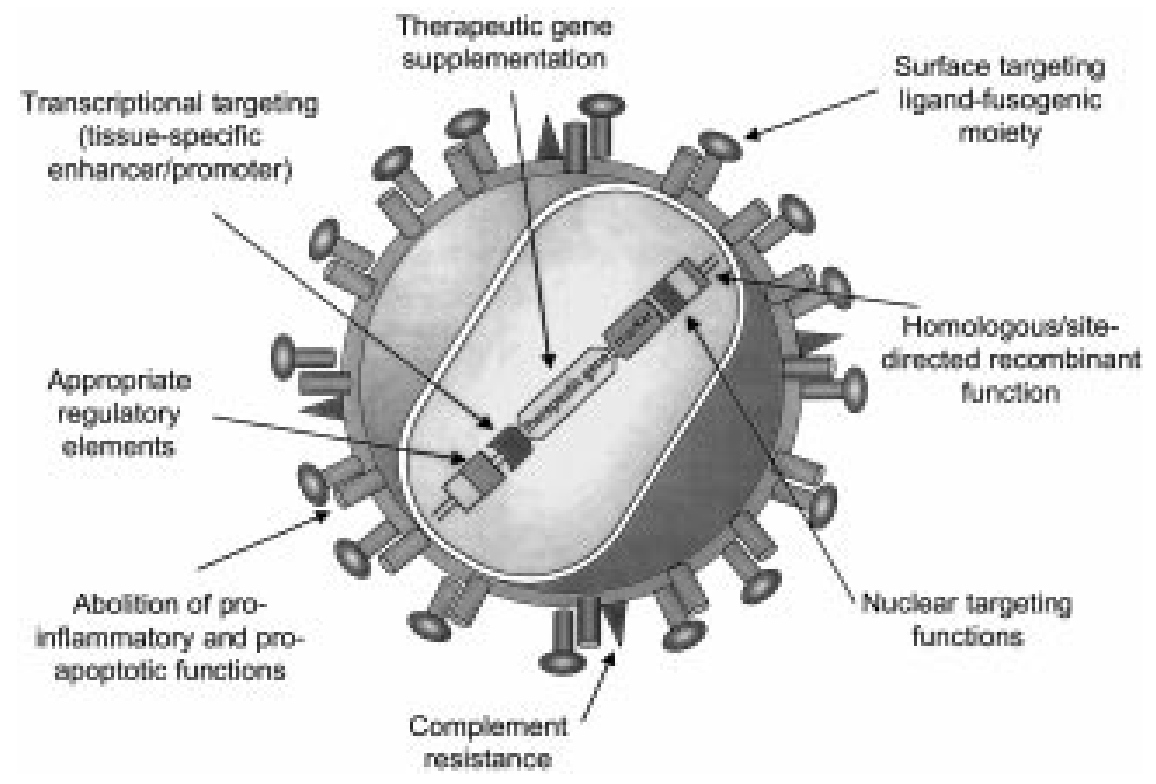

Figure 2 The ideal vector containing hypothetical components to overcome the barriers to gene delivery.

deficiency/dysfunction of a protein is corrected by the introduction of a copy of the wild-type gene that codes for that protein into the affected cells. Indeed, all studies of gene therapy for endocrine diseases published so far,

Table 3 Examples of endocrine-specific promoters/enhancers suitable for the development of transcriptionally targeted gene therapy.

\begin{tabular}{ll}
\hline Cell type & \multicolumn{1}{c}{ Specific promoter/enhancer } \\
\hline Pituitary & \\
PRL-secreting & PRL \\
GH-secreting & GH \\
TSH-secreting & $\beta$-Subunit of TSH \\
FSH/LH-secreting & $\beta$-Subunit of FSH/LH \\
ACTH-secreting & Pro-opiomelanocortin \\
Non-secreting & $\alpha$-Subunit of glycoprotein hormones \\
Thyroid & \\
Follicular & TSH receptor \\
& Thyroglobulin \\
& Thyroperoxidase \\
Parafollicular (C cell) & Codium/iodide symporter \\
Carathyroid & Parathyroid hormone \\
Adrenal cortex & CYP11B1 \\
& CYP11B2 \\
Endocrine pancreas & ACTH receptor \\
$\beta$-Cell & \\
$\alpha$-Cell & Proinsulin \\
Neuroendocrine cells & Proglucagon \\
& Chromogranin A \\
& Somatostatin receptors
\end{tabular}

$\mathrm{TSH}=$ thyrotrophin; $\mathrm{FSH}=$ follicle-stimulating hormone; $\mathrm{LH}=$ luteinising hormone. have employed a gene supplementation approach. However, this strategy has some limits: (i) the gene is often too large and has complex regulatory sequences, so that it cannot be introduced into a vector system; (ii) in some cases, host immune responses against the viral vector reduce transfer efficiency and preclude repeated administration; (iii) some genes require a tightly regulated expression, so that achieving their balanced and functional expression becomes challenging; and (iv) it is difficult to deliver enough vector to the target cells to obtain a therapeutic effect.

An alternative approach is to correct the genetic defect by targeting a dysfunctional exon, or the whole gene, directly substituting it with a correct copy by homologous recombination. The low frequency of homologous recombination in mammalian cells and the possibility of random insertion in the absence of sequence homology are major limitations to this approach (4). A novel technique, which exploits the DNA repair system of the cell, has recently been developed to correct genetic diseases that result from single-point mutations. This technique exploits the possibility of introducing site-specific changes in genomic DNA using oligonucleotides (5). The molecules can be chemically modified so that, upon pairing with the target sequence in the DNA, their chemically reactive group is activated and produces a modification in the genome (6). In this regard, RNA-DNA chimeric oligonucleotides have been designed to contain a sequence complementary to that of the target gene except for a single mismatched nucleotide. The unpaired nucleotide is apparently recognised by endogenous mismatch repair systems, thus altering the sequence of the target gene. This strategy has been successfully used to correct 
point mutations of a variety of genes, including human alkaline phosphatase $(7,8), \beta$-globin (9), factor IX (10) and UDP-glucuronosyltransferase-1 genes (11). It is conceivable that, in the future, a similar approach could be exploitable in a large number of monogenic diseases resulting from single-point mutations, including endocrine diseases, such as congenital adrenal hyperplasia (CAH) due to 21-hydroxylase deficiency.

\section{Corrective gene therapy for monogenic endocrine diseases}

The first disease models for which gene therapy has been envisioned are those resulting from a single gene mutation that can be corrected by supplementing the functional gene. For many endocrine disorders, however, at variance with most inborn errors of metabolism (12), gene therapy should restore not only the missing gene product, but also the intrinsic, strict regulation of native gene expression. Indeed, most hormones are secreted in a pulsatile fashion and show circadian rhythms. Regulated hormone delivery is essential to achieve optimal physiological effects.

\section{Familial hypercholesterolaemia (FH)}

$\mathrm{FH}$ has been one of the first models of monogenic diseases for the development of human gene therapy. This metabolic disorder, caused by the inherited deficiency of the low density lipoprotein (LDL) receptor, is associated with severe hypercholesterolaemia and premature coronary artery disease. The homozygous form of $\mathrm{FH}$ is a good candidate for gene therapy, since it is a lethal disorder refractory to other treatments, such as LDL removal by aphoresis, or orthotopic liver transplantation. The first gene therapy approach developed for FH was an ex vivo approach, using recombinant retroviruses carrying the LDL receptor gene to transduce hepatocytes, initially in animal models (13-15), then in humans $(16,17)$. Treated patients showed long-term improvement of lipid profile without signs of toxicity. An in vivo approach, employing adenoviral vectors to transfer the LDL receptor gene, has been effective in lowering plasma cholesterol levels in mouse (18) and rabbit models $(19,20)$ of $\mathrm{FH}$, even though expression of LDL receptor was transient, partly because of the host immune response. This problem could be in part circumvented by the use of DNAprotein complexes capable of targeting the delivery of the LDL receptor gene to hepatocytes (21) or by the use of recombinant adenoviruses containing the very low density lipoprotein receptor gene, which led to a more prolonged metabolic correction (22). To improve the efficiency of in vivo retrovirus-mediated gene transfer to the liver, partial liver resection and stimulation of hepatocytes proliferation (by cytotoxic thymidine kinase/ganciclovir (GCV) treatment) were combined with repeated injections of retroviral vectors, carrying the LDL receptor gene, into the portal vein of Watanabe LDL receptor-deficient rabbits (23). Amelioration of lipoprotein profile in Watanabe rabbits was obtained also by adenovirus-mediated liver expression of apobec-1, the catalytic subunit of the enzyme complex which is responsible for the synthesis of apolipoprotein B48 (apoB48) mRNA following post-transcriptional editing of the apoB100 mRNA (24). In rabbits, as well as in humans, the liver normally produces only apoB100 mRNA, being unable to edit endogenous hepatic apoB mRNA.

\section{GH deficiency}

$\mathrm{GH}$ deficiency is another candidate disease for gene therapy, since conventional treatment with $\mathrm{GH}$ requires frequent hormone administrations and shows decreased effectiveness with time. The dwarf little (lit/lit) mouse is a model for the human hereditary disorder of isolated $\mathrm{GH}$ deficiency type I. This animal model has reduced serum levels of $\mathrm{GH}$ and insulin-like growth factor-I (IGF-I), due to an inactivating mutation of the GHreleasing factor receptor. One of the first approaches for correcting the growth disorder in this mouse model was based on the injection of a metallothionein-rat GH fusion gene into eggs. Transgenic animals changed their phenotype to giants. Male animals showed improved fertility, whereas female fertility worsened (25).

As an approach for gene therapy of GH deficiency, genetically engineered myoblasts have been successfully used for GH delivery. The first attempt employed myoblasts transduced by retroviral vectors encoding human GH (26). After injection of transduced myoblasts into the murine muscle, human GH could be detected in serum for up to 3 months (26). Implantation of microencapsulated allogenic myoblasts engineered to secrete murine GH into Snell dwarf mice increased linear growth and body weight of treated animals (27). The allogenic myoblasts, which were protected from immune rejection by enclosure in microcapsules, remained functional for at least 6 months (27). Surprisingly, when these encapsulated myoblasts were implanted into normal mice, the treated animals became significantly shorter, lost weight and showed reduced skeletal growth (28). Bioartificial muscles, i.e. tissue-engineered myoblasts organised into organlike structures, have been developed in order to ameliorate in vivo survival and fusion efficiency of tranduced myoblasts (29). Subcutaneous bioartificial muscles secreting recombinant human $\mathrm{GH}$ were able to attenuate host skeletal muscle atrophy in a mouse model in which daily GH injections appeared to be ineffective (30). Primary human skeletal muscle cells isolated from fetuses, normal adults and elderly patients with heart failure could be expanded, genetically modified, and tissue-engineered into implantable bioartificial muscles secreting high levels of GH, similar to the murine skeletal myoblasts (31). 
Muscle-specific enhancers/promoters have been used to produce biologically active $\mathrm{GH}$ or $\mathrm{GH}-$ releasing hormone in differentiated muscle cells (32-34). Even though muscle transcription elements can restrict gene expression to muscle fibres (35) continuous $\mathrm{GH}$ secretion can cause organ hyperplasia $(36,37)$. Ideally, a gene therapy strategy for GH deficiency should mimic the physiological pulsatility of $\mathrm{GH}$ secretion. A controlled release of $\mathrm{GH}$ from skeletal muscle cells has been achieved following implantation of human fibrosarcoma cells into nude mice. These cells expressed two critical domains of a transcription factor as separate polypeptides that interact only in the presence of rapamycin. In cell culture, and in vivo upon transplantation of engineered cells into mice, expression of the therapeutic gene was inducible in a rapamycin dosedependent manner (38). This system allowed long-term regulation of human $\mathrm{GH}$ expression when introduced into mice by i.m. injection of two separate adenoviral or AAV vectors, one encoding an inducible human $\mathrm{GH}$ gene, the other a bipartite rapamycin-regulated transcription factor (39).

Besides myoblasts, other cell types can be used as GH delivery tools. In this respect, rabbit fibroblasts transfected with human GH cDNA were expanded in vitro and implanted under the renal capsule of nude mice, leading to stable delivery of $\mathrm{GH}$ for the life-time of the experimental animals (40). A retroviral vector expressing the porcine $\mathrm{GH}$ cDNA was used to infect primary rat embryo fibroblasts. Transduced fibroblasts were injected into the peritoneum of syngeneic hypophysectomised rats (41). Implanted cells could secrete biologically active GH in vivo, leading to significant skeletal growth up to 57 days postimplantation (41). Microencapsulation and other membrane encapsulation systems can be used to develop non-autologous transduced fibroblast cells for GH delivery $(42,43)$. The use of keratinocytes for ex vivo gene therapy appears to be appealing since these cells can be easily propagated in culture and transferred into human skin. Human GH under the control of human keratin 14 promoter was efficiently produced, secreted, and released into the bloodstream of mice, at levels similar to the circulating GH concentrations in children (44).

Autologous bone marrow stromal cells represent an alternative substrate for $e x$ vivo GH-based gene therapy (45). As for target tissues, the liver is an ideal metabolic factory that is also the natural target of adenoviral vectors. An adenoviral vector expressing rat $\mathrm{GH}$ cDNA was used to induce constitutive GH expression in hepatocytes of GH-deficient lit/lit mice after systemic delivery (36). Treated animals exhibited elevated serum GH values, with restored serum IGF-I concentrations, weight gain, increase in length and normalisation of body composition. Similar results were obtained following i.m. or i.v. injection, or instillation into the duct of the salivary glands of an adenoviral vector encoding the murine GH gene in GH-deficient Snell dwarf mice (46).

\section{Hypothalamic diabetes insipidus}

Hypothalamic diabetes insipidus may be caused by mutations in the arginine vasopressin (AVP) gene. AVP, the anti-diuretic hormone, is synthesised mainly within the supraoptic and paraventricular nuclei of the hypothalamus. After assessing the feasibility of adenovirusmediated transgene expression in the hypothalamus (47), Geddes et al. (48) developed a gene therapy approach for hypothalamic diabetes insipidus. They demonstrated that the stereotactical injection of an adenoviral vector encoding the AVP cDNA into the supraoptic nucleus of the Brattleboro rat, an AVPdeficient animal model of diabetes insipidus, resulted in long-term expression of the gene in magnocellular neurons (48). AVP production was accompanied by reduced daily water intake and urine volume, as well as by increased urine osmolality lasting for up to 4 months. Transient expression of AVP in magnocellular neurons was also demonstrated following injection of naked AVP mRNA into the hypothalamus of Brattleboro rats (49).

\section{CAH}

$\mathrm{CAH}$ is a group of diseases resulting from reduction or lack of activity of one of the enzymes that regulate cortisol synthesis in the adrenal cortex. Patients with $\mathrm{CAH}$ due to 21-hydroxylase deficiency, the most commonly diagnosed enzyme deficiency, cannot adequately synthesise cortisol and mineralocorticoids, leading to an excessive production of adrenocorticotrophin (ACTH) and adrenal androgens. Current treatment is based on steroid replacement, but problems relative to dose adjustment and patient compliance require the development of new therapeutic strategies. The disease is caused by mutations or deletions of the cytochrome P450 21-hydroxylase gene (CYP21). The feasibility of gene therapy for $\mathrm{CAH}$ was evaluated in a mouse model with deletion of the CYP21 gene (50). An adenoviral vector carrying the human CYP21 gene under the control of the cytomegalovirus promoter was injected into the adrenal glands of 21-hydroxylasedeficient mice. The highest expression of CYP21 mRNA was observed 2-7 days after injection, followed by a gradual decline. 21-Hydroxylase activity and corticosterone production also reached levels similar to those found in normal mice. Adrenal morphological abnormalities of 21-hydroxylase-deficient mice, i.e. lack of normal zonation and ultrastructural abnormalities of the mitochondria, were reduced 7 days after genetic treatment. A single intra-adrenal injection of the adenoviral construct did not elicit any immune response, suggesting that the in situ production of high 
levels of steroids has a protective effect, preventing induction of inflammatory responses (50).

\section{Gene therapy for multifactorial endocrine diseases}

Although monogenic diseases were the initial focus of gene therapy, more recently multifactorial diseases, such as diabetes mellitus, cancer and cardiovascular disorders have been considered suitable for genetic intervention.

In this regard, cancer has become one of the most important targets of gene therapy. This development occurred not only because of the poor response shown by many tumours to conventional treatments, but also because of the modern view of cancer as a genetic disease at the somatic level, which implies a deeper understanding of the gene-related mechanisms of cell growth and oncogenesis. The role of the host immune system and the role of apoptosis in controlling tumour progression have been exploited to develop strategies that involve augmentation of immunotherapeutic and chemotherapeutic approaches.

Similarly, the comprehension of the role of genetic mechanisms in multifactorial disorders has favoured the concept that genetic modification might be crucial for the design of new treatments. The pathogenesis of the most common diseases is characterised by an aetiological heterogeneity with the involvement of several genes, besides environmental factors. Such a complexity may hamper the development of genetic approaches to therapy as it was originally conceived for monogenic disorders. This is particularly true for some endocrine diseases, such as diabetes mellitus, which require restoration of the exquisite control of gene expression and response to signals of the pancreatic $\beta$-cells. The fine regulation of gene expression will also be essential in may other endocrine disorders which require the difficult task of introducing appropriate regulatory signals together with the missing gene.

\section{Diabetes mellitus}

Notwithstanding current protocols with diet therapy, insulin supplementation and oral anti-hyperglycaemic drugs, the sharp control of glycaemia, as well as of the long-term complications of the disease, is still problematic. Indeed, diabetes mellitus may be a candidate for a genetic treatment. Potential strategies for gene therapy of diabetes mellitus include: (i) prevention of the autoimmune destruction of $\beta$-cells, and thus of the onset of diabetes; (ii) correction of insulin deficiency; and (iii) prevention of end-organ damages (51).

Prevention of $\beta$-cell autoimmune destruction can be achieved by genetic modification of either the $\beta$-cells or the immune cells (extensively reviewed in (52)).
A strategy to prevent islet damage by induction of tolerance was assessed in animal models of type I diabetes, which received intrathymic injection of islet extracts (53-55) or expressed a proinsulin transgene in the thymus in association with MHC class II molecules (56).

$\beta$-Cell impairment and destruction in autoimmune diabetes is mediated in part by interleukin (IL)- $1 \beta$, produced by immune cells. Gene transfer of the IL-1 receptor antagonist protein to cultured human islets prevented IL-1 $\beta$-induced impairment of the response to a glucose challenge, as well as Fas-triggered apoptosis and nitric oxide production (57). Alternative approaches envisage a reduction in the expression of major histocompatibility molecules (58) or the inhibition of co-stimulatory molecules, such as B7 or its ligand CD28. Indeed, prolonged survival of transplanted $\beta$-cells was observed upon engineering $\beta$-cells to express the fusion protein CTLA4-Ig, which contains cytotoxic T-lymphocyte-associated protein 4 and an IgG1 Fc portion, in order to block CD28-B7 interaction (59).

$\beta$-Cells have also been engineered to secrete molecules that down-modulate the immune response, including IL-4 (60-63), IL-10 (64, 65), transforming growth factor (TGF)- $\beta 1$ (65), the p40 subunit of IL-12 (66), anti-CD40 ligands (67) and the E3 region of adenoviruses (67). Inhibition of cytokines that mediate the inflammatory response, such as interferon (IFN)- $\gamma$ and IL-12, may be a useful tool to treat autoimmune diabetes. To this purpose, i.m. injection of a non-viral vector encoding a soluble IFN- $\gamma$ receptor/IgG1 heavy chain fusion protein was shown to neutralise IFN- $\gamma$ and to prevent the onset of diabetes in experimental models (68).

The transfer of genes encoding for molecules that interfere with the cytocidal activity of activated T-cells or with the apoptotic cascade occurring in $\beta$-cells has been explored as a therapeutic strategy for type I diabetes mellitus. FasL-expressing myoblasts co-transplanted with islets into allogeneic murine hosts significantly prolonged islet survival by eliciting the death of activated T-cells that were highly expressing the Fas receptor (69). At variance, FasL-expressing mouse $\beta$-cells were not protected in transgenic animals and in allografts $(70,71)$, probably due to high susceptibility of pancreatic $\beta$-cells to Fas-mediated death $(70,72)$. Better results were obtained with $\beta$-cells expressing soluble human FasL (73).

Transduction of $\beta$-cells with the $b c l 2$ gene protected them from apoptosis induced by pro-apoptotic cytokines in vitro (74). Similarly, A2O gene transfer to rat islets protected against cytokine-induced apoptosis and cytokine-induced nitric oxide generation (75).

Once $\beta$-cell loss has occurred, gene therapy may be employed to restore $\beta$-cell function, either by promoting $\beta$-cell regeneration or by assisting $\beta$-cell replacement. Endocrine pancreatic precursor cells have been 
demonstrated to persist even in overt diabetes (76). Generation of $\beta$-cells from these precursors has been attempted by expression of a number of differentiation factors, including the vascular endothelial growth factor (VEGF) (77), the islet neogenesis-associated protein (78), the hepatocyte growth factor (79) or members of the reg gene family (80). Better results can be achieved when these factors are used in combination with genes that protect from autoimmune attacks or apoptosis.

Replacement of $\beta$-cells by transplantation of primary human islet cells has proved disappointing because of the difficulty in obtaining enough islets from cadaveric sources. Genetic modification of cells, either $\beta$-cells or other cell types, may provide an efficient source of insulin. There have been many attempts to introduce components of the insulin secretory machinery into non- $\beta$-cells to render them suitable substitutes for $\beta$-cells. A potential advantage of using autologous non- $\beta$-cells is the possibility of evading immune destruction in patients with type I diabetes. To successfully mimic $\beta$-cell function, this approach should provide proinsulin synthesis and processing, along with storage and regulated secretion of mature insulin.

Constitutive proinsulin synthesis has been achieved in a variety of cells, including fibroblasts (81), muscle cells (82), hepatocytes (83-85), pituitary cells (86) and cells of exocrine glands of the gastrointestinal tract (87) both ex vivo and in vivo. Insulin expression could also be activated in non- $\beta$-cells from the endogenous locus as shown by introduction of the gene encoding the transcription factor PDX-1 into a glucagonoma cell line, which resulted in activation of the insulin gene, as well as of other $\beta$-cell genes (88). Correct proinsulin processing can be obtained in non- $\beta$-cells by the introduction of cleavage sites for ubiquitously expressed proteases, such as furin (89) or, conversely, by expression of the $\beta$-cell PC2 and PC3 endoproteases in non$\beta$-cells $(90,91)$.

The reconstitution of regulated insulin secretion in non- $\beta$-cells is a more difficult task. In this regard, glucose responsive promoters (i.e. pyruvate kinase and phosphoenolpyruvate carboxykinase promoters) may be employed to regulate the insulin gene transcription (92). However, these promoters respond to insulin, besides glucose, and, therefore, may be less effective in diabetic people. Moreover, the kinetics of feedback loops based on transcriptional changes are much slower than that of the secretory response, with consequent problems of hypoglycaemia and hyperglycaemia.

An alternative to glucose-regulated insulin gene transcription is insulin-regulated release. Neuroendocrine cells, such as the mouse corticotrophic cell line AtT-20, have been engineered for diabetes mellitus gene therapy approaches, exploiting their secretory apparatus, which includes secretory granules and PC2 and PC3 endoproteases (86). Introduction of the glucose transporter GLUT2 gene and of the glucokinase gene into these cells led to glucose-responsive insulin secretion (93).

The difficulty in reconstituting insulin storage and regulated secretion in non- $\beta$-cells makes exogenous $\beta$-cells the most realistic candidate cell type for replacing defective $\beta$-cell function. Allogeneic and xenogeneic cells have been proposed for $\beta$-cell replacement strategies. Xenogeneic $\beta$-cells have the advantage of being available in potentially unlimited amounts, but they present problems related to graft rejection and to the presence of xenobiotic viruses (94). In this regard, genetically modified pigs have been produced to overcome xenograft hyperacute rejection (95). To obtain an unlimited source of human pancreatic $\beta$-cells, several cell lines from the human fetal and adult pancreas have been developed by expression of dominant oncogenes, but the process of oncogenic transformation leads to dedifferentiation and raises the possibility that unregulated growth might occur in recipients (96). Conditionally transformed $\beta$-cells, in which the expression of the oncogene is under the control of an inducible promoter (97) may be safer, even though the risk of changes during prolonged culture of the cell line remains a problem. Engineering human islet stem cells seems a more reasonable approach to overcome this hurdle $(98,99)$. However, dedifferentiation and loss of insulin synthesis and regulated secretion, due to decreased GLUT2 and glucokinase levels, have been observed also with human islet cells after expansion in vitro (100). Improvements in the ability to culture pancreatic cells in vitro and to maintain the differentiated state might provide the solution to the problem of developing an unlimited source of $\beta$-cells for transplantation. Interesting results have been recently obtained with a human cell line developed from Langerhans islets isolated from a patient with a hyperinsulinaemic hypoglycaemia persisting from infancy (101), a neonatal disease characterised by dysregulation of insulin secretion. Engineering of this cell line by transfection with cDNAs encoding the $\mathrm{K}_{\mathrm{ATP}}$ channel and PDX1 repaired the genetic defects. A glucose-responsive human insulin-secreting cell line was thus obtained, which could be employed for treating the disease and for generating $\beta$-cell lines for cell therapy of diabetes mellitus (101).

\section{Obesity}

Recent understanding of the molecular bases of obesity has allowed design of gene therapy approaches for this disease. Leptin, which is exclusively expressed in adipose tissue, is one of the factors that control satiety, as was demonstrated by the obese (ob/ob) mouse model, which lacks plasma leptin due to a nonsense mutation of the gene (102). Daily administration of recombinant leptin to ob/ob mice was shown to induce weight reduction, appetite suppression, and decreased insulin and glucose blood levels (102-104). In the same 
animal model, a single injection of adenoviral vectors encoding the murine or the human leptin gene was more effective in accelerating weight reduction than a daily injection of recombinant protein. This result suggests that leptin effects are more prominent at the low steady-state levels which can be achieved by gene therapy (105-108). Hyperleptinaemia modified the phenotype of adipocytes, with reduction of fat deposits, down-regulation of lipogenic enzymes and up-regulation of enzymes for fatty acid oxidation (109). The use of helper-dependent adenoviral vectors, in which the sequences coding for the viral protein are completely eliminated, allowed a significant improvement in safety and resulted in an efficient and long-term in vivo delivery of the leptin gene (110). Recombinant AAV vectors may allow long-term expression of therapeutic genes in quiescent cells, such as muscle cells. A single i.m. injection of a recombinant AAV vector encoding mouse leptin in ob/ob mice led to long-term normalisation of metabolic abnormalities, including hyperglycaemia, insulin resistance, impaired glucose tolerance and lethargy (111).

\section{Autoimmune diseases}

Endocrine glands are often targets of autoimmune diseases, resulting in either hormone hyperproduction or hypoproduction, which require adequate correction.

Non-specific immunosuppressive regimens, employed for some autoimmune disorders, are complicated by inherent side-effects, including an increased risk of infections and malignancies. Hence, the ideal therapeutic approach should be able to 'silence' only the inappropriate immune response.

Many autoimmune diseases appear to be mediated by the T helper 1 (Th1) subset of CD4+ cells, which express the pro-inflammatory cytokines IFN- $\gamma$, IL-2 and tumour necrosis factor- $\alpha$. By contrast, regulation of autoimmunity appears to be mediated by Th2 cells, through the synthesis of the anti-inflammatory cytokines IL-4 and IL-10. Correcting the imbalance in the activities of Th1 and Th2 lymphocytes can be envisaged as the most appropriate therapeutic approach for some autoimmune disorders (112).

Gene therapy has already been proposed in several animal models of autoimmune diseases to modify the disease course or just to evaluate the inherent treatment toxicity. The first gene therapy trial for an autoimmune disease was started in 1997 in patients affected by rheumatoid arthritis after positive results had been demonstrated in animal models. The pilot study involved ex vivo retroviral infection of synoviocytes with a gene encoding the IL-1 receptor antagonist (IL-1Ra), which blocks IL-1-induced inflammation. Once the patient's synoviocytes were transduced and tested for absence of infectious contaminants, they were injected intra-articularly. The primary goal of the study was to assess safety, and, after analysis of
IL-1Ra expression, patients underwent joint replacement (113).

One of the great advantages of gene therapy for autoimmune diseases is the ability to deliver diseasemodifying proteins locally, avoiding systemic effects. Clinical trials employing the systemic administration of cytokines, antibodies and anti-receptor molecules, have produced clinical benefit $(114,115)$. However, such an approach can be complicated by emerging sideeffects, among which is generalised immunosuppression. In order to bypass this problem adoption of gene therapy in animal models has sought for effectiveness of the local secretion of 'Th2-like' anti-inflammatory cytokines, such as IL-4 and IL-10, of regulatory cytokines like TGF- $\beta$, or of receptor antagonists like IL-1Ra. The antigen specificity and migratory properties of memory T-cells allow them to serve as an endogenous system for delivering therapeutic transgenes to autoimmune lesions. Such an approach has already been used to treat the animal model of multiple sclerosis, i.e. the murine experimental allergic encephalomyelitis $(116,117)$.

Fas-FasL interaction is required for the maintenance of the immune homeostasis. A failure in this interaction may lead to autoimmune and lymphoproliferative disorders $(118,119)$. Autoreactive T-cells can be eliminated by transferring the gene encoding FasL. Transgenic mice with the FasL gene under control of the insulin promoter have been developed to give protection from insulin-dependent diabetes mellitus (70, 71). However, as mentioned above, lack of protection was observed, probably due to high susceptibility of pancreatic $\beta$-cells to Fas-mediated death $(70,72)$. On the contrary, mice with experimental autoimmune thyroiditis (a murine model of Hashimoto's thyroiditis, characterised by autoreactive T- and B-cell responses and marked lymphocytic infiltration of the gland) showed regression of the disease upon treatment with plasmid DNA coding for FasL under the control of a thyroid-specific promoter (120). Expression of FasL inhibited development of lymphocytic infiltration of the thyroid and induced apoptosis of infiltrating T-cells with total abrogation of the thyroglobulin (TG)-specific cytotoxic T-cell response. The role of gene therapy with FasL for autoimmune thyroiditis in humans remains to be elucidated, as Fas-FasL seems to play a pathogenic role in Hashimoto's thyroiditis (121). A non-viral vector delivery of the IL-10 gene has also been employed in an attempt to treat mice affected by experimental autoimmune thyroiditis (122). The rationale for this approach was given by the curative effects demonstrated by i.v. administration of IL-10 in this animal model (123).

The future goal for gene therapy of endocrine autoimmune disorders is the identification of the best gene, or combination of genes, to use in each disease and of the best system to obtain a long-lasting response. 


\section{Endocrine tumours}

Current approaches for cancer gene therapy (124) can be divided into five categories (Table 4): transfer of genes with direct anti-tumour effects (including antisense oligonucleotides or ribozymes to inhibit oncogenes, or introduction of tumour suppressor genes or genes with anti-angiogenic effects); transfer of genes that activate drugs to their toxic form (suicide genes); transfer of genes that enhance the immune response against cancer (either by genetic modification of tumour cells or by immune effector cells); and transfer of genes which decrease toxicity from chemotherapy, such as the multidrug resistance gene MDR1.

Corrective cancer gene therapy As for most cancers, endocrine tumours result from a multistep process, including loss of cell cycle control, neo-angiogenesis and evasion of immune control. Rarely, endocrine tumours occur as part of an inherited cancer syndrome, such as multiple endocrine neoplasia and the $\mathrm{Li}$-Fraumeni syndrome. Most molecular abnormalities consist of the loss of putative tumour suppressor genes or of the activation of proto-oncogenes. Tumour suppressor genes regulate gene transcription and cell proliferation, and inactivation of both copies of the gene is needed to abrogate the anti-proliferative function. Thus, supplementation of a correct copy of the tumour suppressor gene in cells with homozygous loss of function could restore normal growth, induce tumour cell dormancy or apoptosis. At variance, mutation of only a single copy of a proto-oncogene is required for malignant transformation of a cell. Antisense oligonucleotides, ribozymes, and intracellular single-chain antibodies can be used to reduce the expression of oncogenes.

Gene therapy of cancer, in its most direct form, should aim at replacing a mutated gene with its correct form, or at suppressing the abnormal oncogenic function. At present, however, such a corrective gene therapy faces the insurmountable task that gene replacement, or gene suppression, should simultaneously involve a number of different genes, and should be applied to all tumour cells to reverse the malignant phenotype. Hence, corrective gene therapy

Table 4 Cancer gene therapy strategies.

1. Corrective cancer gene therapy

a. Inactivation of oncogenes by antisense and ribozymes

b. Introduction of tumour suppressor genes

2. Anti-angiogenic gene therapy

3. Suicide gene therapy

4. Immunomodulating gene therapy

a. Active immunisation (modification of tumour cells to enhance immunogenicity or immunisation with genes encoding tumour antigens)

b. Genetic modification of immune effector cells

5. Drug resistance genes to decrease toxicity from chemotherapy seems to be quite difficult to propose as a single therapeutic approach.

Antisense gene therapy by the use of antisense oligonucleotides is aimed at suppressing the expression of a harmful gene, for example a proto-oncogene or a viral gene. Antisense oligonucleotides are short stretches of DNA (about 20 nucleotides in length) or modified DNA that contain a base sequence complementary to a target RNA. By annealing to the target RNA, they interfere with its transport, splicing and translation. In some cases, the hybrid structure between antisense oligonucleotides and target molecules forms a substrate for cellular RNAses. Structural and chemical modifications of oligonucleotides (phophorothioate analogues being the most commonly used) have been developed to enhance affinity and exonuclease resistance, and to reduce toxicity. Non-viral and viral vector systems have been employed to favour oligonucleotides delivery and/or intracellular production. Besides specific antisense effects, oligonucleotides may work via non-antisense mechanisms by binding to growth factors or to their receptors, thus interfering with cellular proliferation, an activity that can be exploited in cancer gene therapy.

Inhibition of target genes can be achieved also by ribozymes. Ribozymes are catalytic RNA molecules that recognise their target RNA in a sequence-specific manner and cleave the RNA strand. Ribozymes may be used as therapeutic tools because of their ability either to inhibit deleterious gene expression (oncogenes, viral transcripts) by cleavage of the target mRNA or even to repair mutant cellular mRNAs $(125,126)$. There are several classes of ribozymes, with either cis-cleaving or trans-cleaving activity, among which are small pathogenic RNAs. These ribozymes contain different catalytic motifs (hammerhead, hairpin, axehead) and flanking arms capable of base-pairing with the substrate. Since the arms of ribozymes that base-pair to substrate RNA are functionally separable from the moieties that effect cleavage, the substrate specificity of ribozymes can be altered, within certain constraints, to allow trans-cleavage of target transcripts. Many of the problems raised by the employment of ribozymes are similar to those outlined for antisense oligonucleotides, i.e. efficient entry into the cell, stability and specificity of substrate targeting.

Some endocrine-related tumours, such as breast and prostate cancer, have been targeted using antisense oligonucleotides or ribozymes. IGFs are important mitogens for a variety of tumour cells, including endocrine cancers and endocrine-related cancers (127). An antiIGF-I receptor antisense strategy has been successfully used against breast cancer cell lines (128). Similarly, cleavage of IGF-II mRNA by a hammerhead ribozyme reduced prostate cancer cells growth (129). Hammerhead ribozymes have also been designed to specifically cleave the androgen receptor mRNA (130) and the oestrogen receptor mRNA (131), which play key roles 
in prostate and breast cancer growth respectively. Transient transfection of prostate cancer cells with the androgen receptor ribozyme led to decreased activity and expression of androgen receptors, without deleterious side-effects (130). Human MCF-7 breast cancer cells proliferation and entry into the $S$ phase of the cell cycle decreased upon treatment with the oestrogen receptor-specific ribozyme (131).

While oncogene alterations are usually dominant, tumour suppressor genes become tumorigenic through loss of function and tend to act in a recessive manner. p53 is the most commonly mutated tumour suppressor gene in human cancer and seems to play a prominent role in some endocrine tumours $(132,133)$. Wild-type p53 protein is involved in G1 cell cycle arrest and apoptosis of DNA-damaged cells, and is therefore crucial in preventing mutation or deletion in functional genes. Restoration of wild-type p53 expression by the introduction of the wild-type $p 53$ gene has recently been used in several cancer models and in human clinical trials of anti-cancer gene therapy (134). Introduction of wild-type $p 53$ in neoplastic cells can significantly inhibit growth and angiogenesis or can induce apoptosis in a variety of p53 mutant cancer cells in vitro, including thyroid carcinomas (135-137). Since the presence of functional $p 53$ has been shown to modulate chemoresistance, another possible advantage of the restoration of wild-type $p 53$ may be sensitisation to chemotherapy and radiotherapy. Indeed, the combination of $p 53$ gene transduction with radiation or chemotherapy resulted in an enhanced cytotoxic effect on thyroid carcinoma cell lines $(137,138)$, even though the effectiveness of p53-based gene therapy was limited to cells carrying an inactive $p 53$ (139).

The cell cycle regulator genes provide an additional target for corrective gene therapy. Among these, the $\mathrm{p} 105 \mathrm{Rb}$ product of the retinoblastoma tumour suppressor gene $(R b)$ is one of the most critical regulators of cellular proliferation. The Rb protein, when unphosphorylated, is responsible for the cell cycle arrest by inhibition of the activity of the E2F family of transcription factors. Normal cell cycle progression requires inactivation of $\mathrm{Rb}$ through phosphorylation by cyclindependent kinases. In humans, $\mathrm{Rb}$ is inactivated in all familial and sporadic retinoblastomas, in $90 \%$ of small cell lung carcinomas, and in a variety of other tumours. Mice with a single wild-type copy of $R b$ $\left(R b^{+/-}\right)$develop $R b$-deficient melanotroph tumours of the pituitary intermediate lobe, and, in some cases, C-cell thyroid carcinomas and hyperplasia of the adrenal medulla $(140,141)$. To evaluate the tumour suppressive potential of the wild-type $R b$ gene in vivo, a recombinant adenoviral vector expressing human $R b$ cDNA was delivered by direct injection into the pituitary intermediate lobe (142). Intratumoural $R b$ transfer decreased tumour cell proliferation, re-established innervation by growth-regulatory dopaminergic neurons, and significantly prolonged the life spans of treated animals compared with controls. Expression of a human $R b$ transgene in the $R b^{+/-}$mice suppressed tumour progression in a variety of tissues (143). Moreover, the frequency of lung metastases in $R b^{+/-}$ mice was reduced by repeated i.v. administration of $R b$ cDNA by non-viral vectors.

Restoration of other tumour suppressor genes expression, such as p16 and p27, may be employed to inhibit growth and to suppress tumorigenicity of endocrine neoplasms (144-147). Indeed, stable transfection of p16 in the mouse pituitary cell line AtT20, which carries a biallelic deletion of the p16 locus, arrested cells in the G1 phase and reduced cell proliferation (148).

Anti-angiogenic gene therapy Tumour growth and metastasis are dependent upon the ability of cancer cells to establish a blood supply through the process known as neoangiogenesis. This complex process is regulated by numerous factors, some being endowed with angiogenic properties, i.e. VEGF, platelet-derived growth factor- $\alpha$, basic fibroblast growth factor (bFGF), epidermal growth factor and IL-8, while others act as endogenous inhibitors of angiogenesis, i.e. thrombospondin-1, platelet factor 4 (PF4), angiostatin and endostatin.

Anti-angiogenic therapies so far devised target different steps of the anti-angiogenic process, by inhibiting expression of angiogenic molecules, by overexpressing anti-angiogenic molecules, or by targeting tumour endothelial cells via endogenous angiogenic inhibitors or artificially constructed targeting ligands. Destruction of tumour vasculature can lead to tumour regression due to apoptosis (149). Gene therapy has been advocated as a means to deliver anti-angiogenic factors to the tumour vasculature. It offers the advantage of high local production of factors with low systemic toxicity. Since the first report of anti-angiogenic gene therapy with a dominant negative mutant of the VEGF receptor (150), new important tools to suppress tumour growth and spread have been developed, which could be employed also for endocrine neoplasms. The main attempts are directed at: (i) suppressing expression of angiogenic factors with antisense oligonucleotides or ribozymes; and (ii) transferring genes that disrupt receptors for angiogenic factors (such as dominant negative functioning extracellular domains of the VEGF receptor flt-1) or encode anti-angiogenic molecules, i.e. thrombospondin-1, PF4, angiostatin and endostatin (151). Although many reports have established the ability of anti-angiogenic gene therapy to inhibit tumour growth and metastatic spread, this therapeutic approach often results in incomplete suppression of tumour growth and metastasis, and no tumour regression (151). This problem may be circumvented in part with a combined gene therapy approach, employing different angiogenesis inhibitors together with cytokine or suicide genes. 
Angiogenesis has been demonstrated to play an important role in tumour cell proliferation and in hormonal secretion of endocrine tumours. Thyroid neoplasms show an increased expression of angiogenic factors, including VEGFs (152-154) and angiopoietin2 , as well as their tyrosine kinase receptors (153). In particular, overexpression of angiopoietin-2 and VEGF is associated with thyroid tumour progression from a prevascular to a vascular phase. Furthermore, thyroid cancers with lymph node spread show increased expression of VEGF-C, whereas aggressive tumours capable of haematogenous spread show a decreased production of trombospondin-1 (153). A higher number of microvessels have been found in papillary thyroid carcinomas with distant recurrences. This finding, even if controversial, has been correlated with disease-free survival $(153,155,156)$. A correlation between microvessel count and prognosis has been suggested also for medullary thyroid carcinomas (156). To investigate the role of VEGF in the angiogenetic process associated with the development of thyroid carcinomas, VEGF was stably transfected into a poorly tumorigenic cell line which expressed low basal levels of VEGF. As compared with parental cells, VEGFoverexpressing cells formed well-vascularised tumours when injected s.c. into nude mice (157). Moreover, antisense suppression of VEGF expression in a highly tumorigenic anaplastic cell line led to the development of small and poorly vascularised tumours in vivo (157). The feasibility of anti-angiogenic therapy to control the growth of anaplastic thyroid carcinomas has been demonstrated also with an inhibitor of angiogenesis in an animal model (158).

Other endocrine tumours may become target of anti-angiogenic therapy. Indeed, angiogenesis plays an important role in the development of the adrenal cortex $(159,160)$ and in adrenocortical tumour cell proliferation (161). Adrenocortical carcinomas seem to be associated with increased endothelial cell proliferation (161), whereas malignant phaeochromocytomas and paragangliomas show an increased number of intratumoural microvessels (162).

The normal anterior pituitary is a well-vascularised tissue, whereas pituitary tumours are less vascular than normal pituitary tissue, suggesting that angiogenesis may be inhibited in these tumours $(163,164)$. However, although these tumours are less vascular overall, they may have induced new vessel development from the systemic circulation, altering oxygen delivery and escaping hypothalamic influences on hormone production (165-167). A series of vasogenic factors are expressed and produced within the pituitary gland, including some factors involved in angiogenesis (168). Pituitary folliculostellate cells can produce both antiangiogenetic factors and angiogenetic factors, including VEGF (169) and bFGF (170). These cytokines act in an autocrine/paracrine manner, and are regulated by hypothalamic factors, such as pituitary adenylate cyclase-activating polypeptide and IL-6 (171). Oestrogen-induced rat pituitary lactotroph tumours and rat pituitary GH/prolactin (PRL)-secreting GH3 tumour cell line overexpress VEGF and its co-receptor neuropilin-1 (172), suggesting a role in the modulation of pituitary tumour angiogenesis. Development of oestrogen-induced rat prolactinomas is also associated with increased expression of pituitary tumour transforming gene (PTTG) and bFGF (173). A concomitant overexpression of PTTG and bFGF has also been demonstrated in human pituitary tumours (173). As oestrogens and bFGF both induce PTTG, and PTTG expression coincides with the early stages of lactotroph cell transformation (from normal to hypertrophic cell), these factors may play a prominent role in pituitary tumorigenesis, and represent potential targets for therapeutic intervention (173).

Suicide gene therapy Suicide gene therapy is defined as the use of a gene that converts a pro-drug into a toxic substance; independently, the gene product and the prodrug are non-toxic. The prototype of this approach exploits the requirement for the intracellular phosphorylation of GCV by the herpes simplex virus thymidine kinase gene product (HSV-TK). Activation generates a toxic drug metabolite that inhibits DNA synthesis, inducing cell death. The specificity of the system can be increased by using tumour-specific promoters upstream of the suicide gene so that the gene is not transcribed within normal tissues. An interesting feature of the HSV-TK/GCV system is the 'bystander' killing of non-transduced cells. The mechanisms that are responsible for this effect have not been fully defined, but are likely to include transfer of non-diffusible phosphorylated GCV to neighbouring cells through gap junctions, endocytosis by non-transduced cells of debris containing toxic GCV, and stimulation of host anti-tumour immune responses. A number of other suicide/prodrug systems have been employed. Among these are: E. coli cytosine deaminase that converts the relatively non-toxic 5-fluorocytosine to the chemotherapeutic agent 5-fluorouracil; cytochrome P-450 2B1 that catalyses cyclophosphamide conversion and ifosfamide activation; E. coli nitroreductase that converts 5-aziridinyl-2,4-dinitrobenzamide to a potent DNA crosslinking agent; and $E$. coli purine nucleoside phosphorylase that generates toxic purine nucleoside analogues (174).

The effectiveness of suicide gene therapy has been explored in a variety of neoplasms, including endocrine tumours. The HSV-TK/GCV scheme was demonstrated to be effective against thyroid and pituitary tumours in cell cultures and in animal models. In this regard, human follicular and anaplastic thyroid carcinoma cell lines, transduced with a retroviral vector containing HSV-TK under the control of the cytomegalovirus promoter, were killed by GCV in a dose- and timedependent manner. Tumour regression was also 
observed in nude mice. A bystander effect and radiosensitisation were documented in vitro and in vivo (175). To develop thyroid-specific retroviral vectors the bovine TG promoter was introduced to control suicide gene expression (176). Selective killing of TG-producing cells was observed upon GCV treatment (176). A synthetic tandemly repeated TG promoter seemed to enhance promoter activity (177). Another strategy to improve TG promoter activity exploited the use of the Cre-loxP system (178). To this end, two recombinant adenoviral vectors were used, one with the Cre recombinase gene under the control of the TG promoter, the other with a stuffer sequence, flanked by the lox $\mathrm{P}$ sequences and including the neo-resistance gene. The latter gene was placed between the strong chimeric CAG promoter and the HSV-TK gene. In this system, the Cre recombinase is expressed when the TG promoter is active, thus removing the stuffer sequence and inducing HSV-TK expression under the transcriptional control of the CAG promoter. The cytotoxic effect of HSV-TK/GCV obtained in vitro with the TG promoter and the Cre-loxP system was 5- to 10-fold higher than that obtained with the TG promoter alone. Enhanced tumour growth inhibition was also observed in in vivo tumour models (178).

A tissue-specific approach was attempted also for medullary thyroid carcinomas, exploiting the promoter sequence of the calcitonin gene to drive selective expression of HSV-TK in tumour cells injected in vivo, with reduced side-effects (179).

Adenoviral vectors have been demonstrated to be effective and safe delivery vehicles for the pituitary gland (3, 180-185). Adenoviral vectors were employed to transduce pituitary adenoma cell lines and animal models with HSV-TK $(181,186)$. Cell-type-specific expression of the therapeutic gene was achieved using the promoters of the $\mathrm{GH}$, glycoprotein hormone $\alpha$-subunit, and PRL genes $(181,187)$. In addition to cell-type-specific expression of the therapeutic gene, regulation of transgene expression is foreseeable for gene therapy of many endocrine disorders. The tetracycline-inducible system, which allows gene expression to be regulated by the tetracycline analogue doxycycline, has been used to develop a PRL-specific and regulatable adenoviral vector $(188,189)$. By driving the expression of the tetracycline transactivator through the PRL-specific promoter, expression of the inducible transgene was restricted to both lactotrophic tumour cell lines and PRL-positive cells in primary anterior pituitary cultures $(188,189)$.

Targeting therapeutic genes to specific cell types is particularly relevant for pituitary adenoma gene therapy in order to spare normal pituitary cells and neighbouring tissues. This aim could be also achieved by retargeting viral vector tropism so that the vectors recognise and bind pituitary-specific surface molecules, such as hypothalamic hormone receptors, which are often overexpressed in pituitary tumours (190, 191).
Recombinant temperature-sensitive HSV type 1 vectors have been employed for gene transfer into tumours and normal anterior pituitary cells (192). However, neurovirulence of this vector system limits its potential use for gene therapy in humans, even though it can be used as a delivery system to generate transient transgenesis for biological studies (193).

Transcriptionally targeted gene therapy is feasible also for other endocrine cancers, exploiting cis-acting regulatory sequences of tissue-specific genes. Promoter/ enhancer elements of steroidogenetic enzymes could be employed to target transgene expression in steroidsecreting cells. A chimeric enhancer/promoter element, containing both the CYP11B1 promoter and the P450SCC enhancer was employed to target HSV-TK expression in adrenocortical carcinoma cells. HSV-TK expression and GCV sensitivity of stably transfected adrenal cancer cells was enhanced by treatment with factors acting through the cAMP pathway, such as ACTH (194).

A limitation for targeted gene therapy approaches employing enhancer/promoter elements of genes expressed by differentiated cells, such as hormones, receptors or enzymes, is the risk of decreased transgene expression in tumour cells due to dedifferentiation. To overcome this problem, regulatory sequences of genes that are highly and specifically expressed in malignant cells, such as IGF-II in adrenocortical carcinomas (195) or oncofetal fibronectin in thyroid carcinomas (196), should be employed.

The iodide-concentrating ability of thyroid cells, which is based on the tissue-specific expression of the sodium/iodide symporter gene (NIS), allows for diagnostic radionuclide thyroid imaging with ${ }^{123} \mathrm{I}$ and

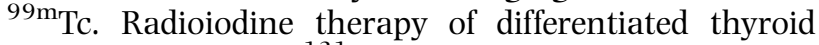
carcinomas using ${ }^{131} \mathrm{I}$ can also be pursued, with minimal systemic side-effects, except for the need for replacement therapy. The rat NIS has been transferred into cancer cells by a retroviral vector to mimic the iodide uptake of thyroid follicular cells. NIS-mediated accumulation of ${ }^{123} \mathrm{I}$ by transduced cancer cells allowed scintigraphic detection of tumours in vivo. Selective killing of NIS-transduced cells by the induced accumulation of ${ }^{131}$ I was demonstrated in vitro (197). Thus, NIS-based gene therapy may have both diagnostic and therapeutic applications for cancer.

Morbidity and mortality of patients with endocrine tumours are often due more to hormone overproduction rather than to metastatic disease. In some cases refractory to conventional surgical and pharmacological treatment, such as Cushing's syndrome, acromegaly and endocrine pancreatic tumours, gene therapy may be an effective approach. In this regard, human lactotroph adenoma cells have been transduced with an adenoviral vector encoding tyrosine hydroxylase, a rate-limiting enzyme in the biosynthesis of dopamine, in an attempt to decrease PRL release (3). A similar approach could be used for other types 
of tumours. For example, GH-secreting adenomas could be treated with somatostatin gene transfer.

Immunomodulating gene therapy Immunomodulating gene therapy has been developed in an attempt to stimulate cellular immune responses against tumourspecific antigens. One method is to genetically modify the tumour cell to have it express cytokines (e.g. IL-2, IL-12, granulocyte-macrophage colony-stimulating factor, or IFN- $\gamma$ ) that attract antigen-presenting cells such as dendritic cells and macrophages, and to activate a systemic T-cell immune response. Another method is to genetically modify the tumour cell itself to become a professional antigen-presenting cell through the expression of MHC molecules, co-stimulatory molecules such as B-7, and cytokines genes necessary for T-cell activation and proliferation. To avoid costly and timeconsuming processes involved in generating tumour vaccines by ex vivo approaches, in vivo strategies to enhance immune response have been developed, such as vector-mediated delivery of cytokine genes.

Another immunological approach involves the use of vectors for the expression of tumour-associated antigens (vaccines). Recombinant vaccines may be either viral, bacterial or 'naked' DNA (198). Recombinant viral vaccines offer the advantage of intrinsic immunogenicity, whereas bacterial vaccines have cellular tropism for monocytes and macrophages, and possess enteric routes of infection, providing the possibility of oral delivery (198). 'Naked' DNA vaccines, which can persist and express encoded genes for long periods of time after i.m. injection, have been demonstrated to mediate both antibody-mediated and cellular immune responses against encoded gene products, even if they are less potent than other recombinant vaccines (199).

Another potential method of manipulating the immune response against cancer is to utilise dendritic cells (200), which are highly potent antigen-presenting cells capable of stimulating and activating quiescent lymphocytes. Stable introduction of tumour-antigen genes into dendritic cells may allow presentation of multiple immunogenic epitopes of the same antigen, as well as the constitutive expression of the antigen in vivo. In addition, introduction of cytokine genes into dendritic cells may enhance the anti-tumour response.

Genetic immunotherapy showed interesting results in a model of medullary thyroid carcinoma in vitro and in vivo. In vitro infection of murine medullary thyroid carcinoma cells with an adenoviral vector harbouring the mouse IL-2 gene abrogated their tumorigenicity and induced a long-lasting state of immunity in syngeneic BALB/C mice (201). In vivo, intratumour injection of the adenoviral vector resulted in the rejection and/or stabilisation of pre-established tumours in treated mice (202) without significant toxicity to other organs (203).
Combined gene therapy approach A new treatment strategy combining two different modalities, enzymedirected prodrug activation (tumour suicide) along with cytokine-promoted tumour rejection, has been recently devised to amplify the anti-tumour response, and proved to be efficacious in animal models (204). A bicistronic retroviral vector co-expressing HSV-TK and human IL-2 genes has been designed to pursue this new approach of cancer gene therapy in humans $(205,206)$ and successfully employed in a pilot study to treat four patients with recurrent glioblastoma multiforme (207, 208). A similar construct has been developed to treat human thyroid carcinomas. In this regard, the HSV-TK and human IL-2 genes, separated by an internal ribosome entry site to allow the simultaneous expression of the two genes from the same transcript, were cloned into the MFG retroviral vector. Transcriptionally targeted thyroid-specific vectors were generated replacing the viral enhancer in the long terminal repeat with the enhancer sequence of the human TG gene (209). In vitro experiments showed selective killing of transduced thyroid carcinoma cells by GCV treatment, and secretion of biologically active IL-2. Such a combined approach, employing both cytokine and suicide genes, seems to elicit a potentiated anti-cancer effect in vivo, as observed in a mouse model of medullary thyroid carcinoma inoculated with both HSV-TK-transduced carcinoma cells and IL-2-transfected cells (210).

\section{Conclusions}

Scientific progress in biomedical research has revealed the molecular mechanisms of many human diseases. Although several endocrine disorders are caused by the inheritance of a single, functionally defective gene, the molecular bases of most endocrine diseases relate to acquired genetic defects. These defects would eventually require an aetiological (non-pharmacological) genetic intervention. Present premises seem to favour intervention for endocrine tumours, but many combined approaches of cell and gene therapy are foreseeable also for endocrine and metabolic disorders.

\section{Acknowledgements}

This work was supported by IPSEN SpA and by MURST (no. 990619 8577), Regione Veneto (no. 966/02/00) and University of Padova funds.

\section{References}

1 The Journal of Gene Medicine, www.wiley.co.uk/genmed.

2 Wilson JD, Foster DW, Kronemberg H \& Larsen PR. Principles of Endocrinology. In William's Textbook of Endocrinology. pp 1-10. Eds JD Wilson \& DW Foster. W B Saunders Company 1998

3 Freese A, During MJ, Davidson BL, Gennarelli TA, Kaplitt MG, Flamm ES et al. Transfection of human lactotroph adenoma cells with an adenovirus vector expressing tyrosine hydroxylase 
decreases prolactin release. Journal of Clinical Endocrinology and Metabolism 199681 2401-2404.

4 Smithies O, Gregg RG, Boggs SS, Koralewski MA \& Kucherlapati RS. Insertion of DNA sequences into the human chromosomal beta-globin locus by homologous recombination. Nature 1985317 230-234.

5 Moerschell RP, Tsunasawa S \& Sherman F. Transformation of yeast with synthetic oligonucleotides. PNAS 198885 524-528.

6 Wang G, Seidman MM \& Glazer PM. Mutagenesis in mammalian cells induced by triple helix formation and transcriptioncoupled repair. Science 1996271 802-805.

7 Yoon K, Cole-Strauss A \& Kmiec EB. Targeted gene correction of episomal DNA in mammmalian cells mediated by a chimeric RNA-DNA oligonucleotide. PNAS 199693 2071-2076.

8 Kren BT, Cole-Strauss A, Kmiec EB \& Steer CJ. Targeted nucleotide exchange in the alkaline phosphatase gene of HuH-7 cells mediated by a chimeric RNA/DNA oligonucleotide. Hepatology 199725 1462-1468.

9 Cole-Strauss A, Yoon K, Xiang Y, Byrne BC, Rice MC, Gryn J et al. Correction of the mutation responsible for sickle cell anemia by an RNA-DNA oligonucleotide. Science 1996273 1386-1389.

10 Kren BT, Bandyopadhyay P \& Steer CJ. In vivo site-directed mutagenesis of the factor IX gene in rat liver and isolated hepatocytes by chimeric RNA/DNA oligonucleotides. Nature Medicine 19984 285-290.

11 Kren BT, Parashar B, Bandyopadhyay P, Chowdhury NR, Chowdhury JR \& Steer CJ. Correction of the UDP-glucoronosyltransferase gene defect in the Gunn rat model of Crigler-Najjar syndrome type I with a chimeric oligonucleotide. PNAS 199996 10349-10354.

12 Kay MA \& Woo SLC. Gene therapy for metabolic disorders. Trends in Genetics 199410 253-257.

13 Wilson JM, Grossman M, Wu CH, Chowdhury NR, Wu GY \& Chowdhury JR. Hepatocyte-directed gene transfer in vivo leads to transient improvement of hypercholesterolemia in low density lipoprotein receptor-deficient rabbits. Journal of Biological Chemistry 1990267 963-967.

14 Chowdhury JR, Grossman M, Gupta S, Chowdhury NR, Baker JR Jr \& Wilson JM. Long-term improvement of hypercholesterolemia after ex vivo gene therapy in LDLR-deficient rabbits. Science $19912541802-1805$.

15 Grossman M, Raper S \& Wilson J. Transplantation of geneticallymodified autologus hepatocytes into nonhuman primates: feasibility and short-term toxicity. Human Gene Therapy 19923 501-510.

16 Grossman M, Raper SE, Kozarsky K, Stein EA, Engelhardt JF, Muller D et al. Successful ex vivo gene therapy directed to liver in a patient with familial hypercholesterolemia. Nature Genetics 19946 335-341.

17 Grossman M, Rader DJ, Muller DW, Kolansky K, Clark BJ III, Stein EA et al. A pilot study of ex vivo gene therapy for homozygous familial hypercholesterolemia. Nature Medicine 19951 $1148-1154$.

18 Ishibashi S, Brown M, Goldstein J, Gerard R, Hammer R \& Herz J. Hypercholesterolemia in low density lipoprotein receptor knockout mice and its reversal by adenovirus-mediated gene delivery. Journal of Clinical Investigation 199392 883-893.

19 Kozarsky K, McKinley D, Austin L, Raper S, StratfordPerricaudet L \& Wilson JM. In vivo correction of LDL receptor deficiency in the Watanabe hereditable defective hyperlipidemic rabbit with recombinant adenoviruses. Journal of Biological Chemistry 1994269 13695-13702.

20 Li J, Fang B, Eisensmith R, Li X, Nasonkin I, Lin-Lee Yet al. In vivo gene therapy for hyperlipidemia: phenotypic correction in Watanabe rabbits by hepatic delivery of the rabbit LDL receptor gene. Journal of Clinical Investigation 199595 768-773.

21 Wilson JM, Grossman M, Raper SE, Baker JR Jr, Newton RS \& Thoene JG. Ex vivo gene therapy of familial hypercholesterolemia. Human Gene Therapy 19923 179-222.
22 Kozarsky KF, Jooss K, Donahee M, Strauss JF III \& Wilson JM. Effective treatment of familial hypercholesterolemia in the mouse model using adenovirus-mediated transfer of the VLDL receptor gene. Nature Genetics 199613 54-62.

23 Pakkanen TM, Laitinen M, Hippelainen M, Kallionpaa H, Lehtolainen P, Leppanen $\mathrm{P}$ et al. Enhanced plasma cholesterol lowering effect of retrovirus-mediated LDL receptor gene transfer to WHHL rabbit liver after improved surgical technique and stimulation of hepatocyte proliferation by combined partial liver resection and thymidine kinase-ganciclovir treatment. Gene Therapy $1999634-41$.

24 Kozarsky KF, Bonen DE, Giannoni F, Funahashi T, Wilson JM \& Davidson NO. Hepatic expression of the catalytic subunit of the apolipoprotein B mRNA editing enzyme (apobec-1) ameliorates hypercholesterolemia in LDL receptor-deficient rabbits. Human Gene Therapy 19967 943-957.

25 Hammer RE, Palmiter RD \& Brinster RL. Partial correction of murine hereditary growth disorder by germ-line incorporation of a new gene. Nature $198431165-67$.

26 Dhawan J, Pan LC, Pavlath GK, Travis MA, Lanctot AM \& Blau HM. Systemic delivery of human growth hormone by injection of genetically engineered myoblasts. Science 1991254 1509-1512.

27 Al-Hendy A, Hortelano G, Tannenbaum GS \& Chang PL. Correction of the growth defect in dwarf mice with nonautologous microencapsulated myoblasts - an alternate approach to somatic gene therapy. Human Gene Therapy 19956 165-175.

28 Al-Hendy A, Hortelano G, Tannenbaum GS \& Chang PL. Growth retardation - an unexpected outcome from growth hormone gene therapy in normal mice with microencapsulated myoblasts. Human Gene Therapy 19967 61-70.

29 Vandenburgh HH, Del Tatto M, Shansky J, Lemaire J, Chang A, Payumo $\mathrm{F}$ et al. Tissue engineered skeletal muscle organoids for reversible gene therapy. Human Gene Therapy 19967 2195-2200.

30 Vandenburgh HH, Del Tatto M, Shansky J, Goldstein L, Russell K, Genes $\mathrm{N}$ et al. Attenuation of skeletal muscle wasting with recombinant human growth hormone secreted from a tissueengineered bioartificial muscle. Human Gene Therapy 19989 2555-2564.

31 Powell C, Shansky J, Del Tatto M, Forman DE, Hennessey J, Sullivan $\mathrm{K}$ et al. Tissue-engineered human bioartificial muscle expressing a foreign recombinant protein for gene therapy. Human Gene Therapy 199910 565-577.

32 Daheler A, Wade RP, Muscat GE \& Waters MJ. Expression vectors encoding human growth hormone (hGH) controlled by human muscle-specific promoters: prospects for regulated production of hGH delivered by myoblast transfer or intravenous injection. Gene 1994145 305-310.

33 Draghia-Akli R, Fiorotto ML, Hill LA, Malone PB, Deaver DR \& Schwartz RJ. Myogenic expression of an injectable proteaseresistant growth hormone-releasing hormone augments longterm growth in pigs. Nature Biotechnology $1999171179-1183$.

34 Anwer K, Shi M, French MF, Muller SR, Chen W, Liu Q et al. Systemic effect of human growth hormone after intramuscular injection of a single dose of a muscle-specific gene medicine. Human Gene Therapy 19989 659-670.

35 Skarli M, Kiri A, Vrbova G, Lee CA \& Goldspik G. Myosin regulatory elements as vectors for gene transfer by intramuscular injection. Gene Therapy 19985 514-520.

36 Hahn TM, Copeland KC \& Woo SLC. Phenotypic correction of dwarfism by constitutive expression of growth hormone. Endocrinology $19961374988-4993$.

$37 \mathrm{Ng}$ ST, Zhou JA, Adesanya OO, Wang J, LeRoith D \& Bondy CA. Growth hormone treatment induces mammary gland hyperplasia in ageing. Nature Medicine 19973 1141-1149.

38 Riviera VM, Clackson T, Natesan S, Pollock R, Amara JF, Keenan T et al. A humanised system for pharmacological control of gene expression. Nature Medicine 19962 1028-1032. 
39 Rivera VM, Ye X, Courage NL, Sachar J, Cerasoli F Jr, Wilson JM et al. Long-term regulated expression of growth hormone in mice after intramuscular gene transfer. PNAS 199996 8657-8662.

40 Heartlein MW, Roman VA, Jiang J-L, Sellers JW, Zuliani AM, Treco DA et al. Long-term production and delivery of human growth hormone in vivo. PNAS 199491 10967-10971.

41 Chen BF, Chang WC, Chen ST, Chen DS \& Hwang LH. Longterm expression of the biologically active growth hormone in genetically modified fibroblasts after implantation into a hypophysectomized rat. Human Gene Therapy 19956 917-926.

42 Cheng WT, Chen BC, Chiou ST \& Chen CM. Use of nonautologous microencapsulated fibroblasts in growth hormone gene therapy to improve growth of midget swine. Human Gene Therapy 19989 1995-2003.

43 Josephs SF, Loudovaris T, Dixit A, Young SK \& Johnson RC. In vivo delivery of recombinant human growth hormone from genetically engineered human fibroblasts implanted within Baxter immunoisolation devices. Journal of Molecular Medicine $199977211-214$

44 Wang X. Zinkel S, Polonsky K \& Fuchs E. Transgenic studies with a keratin promoter-driven growth hormone transgene: prospects for gene therapy. PNAS 199794 219-226.

45 Hurwitz DR, Kirchgesser M, Merrill W, Galanopoulos T, McGrath CA, Emami S et al. Systemic delivery of human growth hormone or human factor IX in dogs by reintroduced genetically modified autologous bone marrow stromal cells. Human Gene Therapy 19978 137-156.

46 Marmary Y, Parlow AF, Goldsmith CM, He X, Wellner RB, Satomura $\mathrm{K}$ et al. Construction and in vivo efficiency of a replication-deficient recombinant adenovirus encoding murine growth hormone. Endocrinology 1999140 260-265.

47 Geddes BJ, Harding TC, Hughes DS, Byrnes AP, Lightman SL, Conde $\mathrm{G}$ et al. Persistent transgene expression in the hypothalamus following stereotaxic delivery of a recombinant adenovirus: suppression of the immune response with cyclosporin. Endocrinology 1996137 5166-5169.

48 Geddes BJ, Harding TC, Lightman SL \& Uney JB. Long-term gene therapy in the CNS: reversal of hypothalamic diabetes insipidus in the Brattleboro rat by using an adenovirus expressing arginine vasopressin. Nature Medicine 19973 1402-1404.

49 Jirikowski GF, Sanna PP, Maciejewski-Lenoir D \& Bloom FE. Reversal of diabetes insipidus in Brattleboro rats: intrahypothalamic injection of vasopressin mRNA. Science 1992255 996-998.

50 Tajima T, Okada T, Ma X-M, Ramsey WJ, Bornstein SR \& Aguilera G. Restoration of adrenal steroidogenesis by adenovirus-mediated transfer of human cytochrome P450 21hydroxylase into the adrenal gland of 21-hydroxylase-deficient mice. Gene Therapy 19996 1898-1903.

51 Levine F \& Leibowitz G. Towards gene therapy of diabetes mellitus. Molecular Medicine Today 19995 165-171.

52 Giannoukakis N, Rudert WA, Robbins PD \& Trucco M. Targeting autoimmune diabetes with gene therapy. Diabetes 199948 2107-2121.

53 Posselt AM, Barker CF, Friedman AL \& Naji A. Prevention of autoimmune diabetes in the BB rat by intrathymic islet transplantation at birth. Science 1992256 1321-1324.

54 Koevary SB \& Blomberg M. Prevention of diabetes in BB/Wor rats by intrathymic islet injection. Journal of Clinical Investigation $199289512-516$.

55 Charlton B, Taylor-Edwards C, Tisch R \& Fathman CG. Prevention of diabetes and insulitis by neonatal intrathymic islet administration in NOD mice. Journal of Autoimmunity 1994 7 549-560.

56 French MB, Allison J, Cram DS, Thomas HE, Dempsey-Collier M, Silva A et al. Transgenic expression of mouse proinsulin II prevents diabetes in nonobese diabetic mice. Diabetes 199746 34-39.
57 Giannoukakis N, Rudert WA, Ghivizzani S, Ricordi C, Trucco M \& Robbins PD. Adenoviral gene transfer of the human interleukin-1 receptor antagonist protein to human islets prevents IL-1- $\beta$-induced dysfunction and apoptosis activation in vivo. Diabetes 199948 1730-1736.

58 Von Herrath MG, Efrat S, Oldstone MB \& Horwitz MS. Expression of adenoviral E3 transgenes in beta cells prevents autoimmune diabetes. PNAS $1997949808-9813$.

59 Gainer AL, Korbutt GS, Rajotte RV, Warnock GL \& Elliott JF. Expression of CTLA4-Ig by bioballistically transfected mouse islets promotes islet allograft survival. Transplantation 199763 1017-1021.

60 Mueller R, Krahl T \& Sarvetnick N. Pancreatic expression of interleukin-4 abrogates insulitis and autoimmune diabetes in nonobese diabetic (NOD) mice. Journal of Experimental Medicine 1996184 1093-1099.

61 Gallichan WS, Balasa B, Davies JD \& Sarvetnick N. Pancreatic IL-4 expression results in islet-reactive Th2 cells that inhibit diabetogenic lymphocytes in the nonobese diabetic mouse. Journal of Immunology 1999163 1696-1703.

62 Davies JD, Mueller R, Minson S, O'Connor E, Krahl T \& Sarvetnik N. Interleukin-4 secretion by the allograft fails to affect the allograft-specific interleukin-4 response in vitro. Transplantation 199967 1583-1589.

63 Benhamou PY, Mullen Y, Shaked A, Bahmiller D \& Csete ME. Decreased alloreactivity to human islets secreting recombinant viral interleukin 10. Transplantation 199662 1306-1312.

64 Deng S, Ketchum RJ, Kucher T, Weber M, Shaked A, Naji A et al. IL-10 and TGF- $\beta$ gene transfer for xenogeneic islet transplantation: comparison of effect in concordant vs discordant combination. Transplantation Proceedings 199729 2204-2205.

65 Lee MS, Sawyer S, Arnush M, Krahl T, Von Herrath M, Oldstone MA et al. Transforming growth factor- $\beta$ fails to inhibit allograft rejection or virus-induced autoimmune diabetes in transgenic mice. Transplantation 199661 3950-3956.

66 Balasa B, Krahl T, Patstone G, Lee J, Tisch R, McDevitt HO et al. CD40 ligand-CD40 interactions are necessary for the initiation of insulitis and diabetes in nonobese diabetic mice. Journal of Immunology $19971594620-4627$.

67 Von Herrath MG, Efrat S, Oldstone MB \& Horwitz MS. Expression of adenoviral E3 transgenes in beta cells prevents autoimmune diabetes. PNAS $1997189808-9813$.

68 Prud'homme GJ \& Chang Y. Prevention of autoimmune diabetes by intramuscular gene therapy with a nonviral vector encoding an interferon-gamma receptor/IgG1 fusion protein. Gene Therapy $19996771-777$.

69 Lau HT, Yu M, Fontana A \& Stoeckert CJ Jr. Prevention of islet allograft rejection with engineered myoblasts expressing FasL in mice. Science 1996273 109-112.

70 Chervonsky AV, Wang Y, Wong FS, Visintin I, Flavell RA, Janeway CA Jr et al. The role of FasL in autoimmune diabetes. Cell 199789 17-24.

71 Allison J, Georgiou HM, Strasser A \& Vaux DL. Transgenic expression of CD95 ligand on islet B cells induces a granulocytic infiltration but does not confer immune privilege upon islet allografts. PNAS 199794 3943-3947.

72 Stassi G, De Maria R, Trucco G, Rudert W, Testi T, Galluzzo A et al. Nitric oxide primes pancreatic B cells for Fas-mediated destruction in insulin-dependent diabetes mellitus. Journal of Experimental Medicine 1997186 1193-1200.

73 Leibowitz G, Beattie GM, Kafri T, Cirulli V, Lopez AD, Hayek A et al. Gene transfer to human pancreatic endocrine cells using viral vectors. Diabetes 199948 745-753.

74 Liu Y, Rabinovitch A, Suarez-Pinzon W, Muhkerjee B, Brownlee M, Edelstein D et al. Expression of the $b c l-2$ gene from a defective HSV-1 amplicon vector protects pancreatic beta-cells from apoptosis. Human Gene Therapy 19967 1719-1726.

75 Grey ST, Arvelo MB, Hasenkamp WM, Bach FH \& Ferran C. Adenovirus-mediated gene transfer of the anti-apoptotic protein 
A20 in rodent islets inhibits IL-1 beta-induced NO release. Transplantation Proceedings 199931789.

76 Slack JMW. Developmental biology of the pancreas. Development 1995121 1569-1580.

77 Rooman I, Schuit F \& Bouwens L. Effects of vascular endothelial growth factor on growth and differentiation of pancreatic ductal epithelium. Laboratory Investigation $1997 \mathbf{7 6}$ $225-232$.

78 Rafaeloff R, Pittenger GL, Barlow SW, Quin XF, Yan B, Rosemberg L et al. Cloning and sequencing of the pancreatic islet neogenesis associated protein (INGAP) gene and its expression in islets neogenesis in hamster. Journal of Clinical Investigation 199799 2100-2109.

79 Lefebvre VH, Otonkoski T, Ustinov J, Huotari MA, Pipeleers DG \& Bouwens L. Culture of adult human islet preparations with hepatocyte growth factor and $804 \mathrm{G}$ matrix is mitogenic for duct cells but not for $\beta$-cells. Diabetes 199847 134-137.

80 Bone AJ, Banister SH \& Zhang S. The REG gene and islet cell repair and renewal in type 1 diabetes. Advances in Experimental Medicine and Biology 1997426 321-327.

81 Falqui L, Martinenghi S, Severini GM, Corbella P, Taglietti MV, Arcelloni $\mathrm{C}$ et al. Reversal of diabetes in mice by implantation of human fibroblasts genetically engineered to release mature human insulin. Human Gene Therapy 199910 1753-1762.

82 Simonson GD, Groskreutz DJ, Gorman CM \& MacDonald MJ. Synthesis and processing of genetically modified human proinsulin by rat myoblast primary cultures. Human Gene Therapy $1996771-78$

83 Simpson AM, Tuch BE, Swan MA, Tu J \& Marshall GM. Functional expression of the human insulin gene in a human hepatoma cell line (HEP G2). Gene Therapy 19952 223-231.

84 Valera A, Fillat C, Costa C, Sabater J, Visa J, Pujol A et al. Regulated expression of human insulin in the liver of transgenic mice corrects diabetic alterations. FASEB Journal 19948 440-447.

85 Kolodka TM, Finegold M, Moss L \& Woo SL. Gene therapy for diabetes mellitus in rats by hepatic expression of insulin. PNAS 199592 3293-3297.

86 Lipes MA, Cooper EM, Skelly R, Rhodes CJ, Boschetti E, Weir GC et al. Insulin-secreting non-islet cells are resistant to autoimmune destruction. PNAS 199693 8595-8600.

87 Goldfine ID, German MS, Tseng HC, Wang J, Bolaffi JL, Chen JW et al. The endocrine secretion of human insulin and growth hormone by exocrine glands of the gastrointestinal tract. Nature Biotechnology 199715 1378-1382.

88 Serup P, Jenses J, Andersen FG, Jorgensen MC, Blume N, Holst JJ et al. Induction of insulin and islet amyloid polypeptide production in pancreatic islet glucagonoma cells by insulin promoter factor 1. PNAS 199693 9015-9020.

89 Groskreutz DJ, Sliwkrowski MX \& Gorman CM. Genetically engineered proinsulin constitutively processed and secreted as mature, active insulin. Journal of Biological Chemistry 1994269 6241-6245.

90 Vollenweider F, Kaufmann J, Irminger JC \& Halban PA. Processing of proinsulin by furin, PC2, and PC3 in (co)transfected COS (monkey kidney) cells. Diabetes 199544 1075-1080.

91 Kaufmann JE, Irminger J-C, Mungall J \& Halban PA. Proinsulin conversion in GH3 cells after coexpression of human proinsulin with the endoproteases PC2 and/or PC3. Diabetes 1997 46 978-982.

92 Mitanchez D, Doiron B, Chen R \& Kahn A. Glucose-stimulated genes and prospects of gene therapy for type I diabetes. Endocrine Reviews 199718 520-540.

93 Hughes SD, Quaade C, Johnson JH, Ferber S \& Newgard CB. Transfection of AtT-20ins cells with GLUT-2 but not GLUT-1 confers glucose stimulated insulin secretion. Journal of Biochemical Chemistry 1993268 15205-15212.

94 Wilson CA, Wong S, Muller J, Davidson CE, Rose TM \& Burd P. Type $C$ retrovirus released from porcine primary peripheral blood mononuclear cells infects human cells. Journal of Virology $1998723082-3087$.

95 Platt JL. New directions for organ transplantation. Nature 1998 $39211-17$.

96 Wang S, Beattie GM, Mally MI, Cirulli V, Itkin-Ansari P, Lopez $\mathrm{AD}$ et al. Isolation and characterisation of a cell line from the epithelial cells of the human fetal pancreas. Cell Transplantation 19976 59-67.

97 Efrat S, Fusco-Demane D, Lemberg H, Emran OA \& Wang X. Conditional transformation of a pancreatic $\beta$-cell line derived from transgenic mice expressing a tetracycline-regulated oncogene. PNAS $1995923576-3580$.

98 Beattie GM, Cirulli V, Lopez AD \& Hayek A. Ex vivo expansion of human pancreatic endocrine cells. Journal of Clinical Endocrinology and Metabolism 199782 1852-1856.

99 Cornelius JG, Techernev V, Kao KJ \& Peck AB. In vitro generation of islets in long-term cultures of pluripotent stem cells from adult mouse pancreas. Hormone and Metabolic Research $199729271-277$.

100 Beattie GM, Itkin-Ansari P, Cirulli V, Leibowitz G, Lopez AD, Bossie S et al. Sustained proliferation of PDX-1 positive cells derived from human islets. Diabetes 199948 1013-1019.

101 MacFarlane WM, Chapman JC, Shepherd RM, Hashmi MN, Kamimura N, Cosgrove KE et al. Engineering a glucoseresponsive human insulin-secreting cell line from islet of Langerhans isolated from a patient with persistent hyperinsulinemic hypoglycemia of infancy. Journal of Biological Chemistry $200027434059-34066$.

102 Halaas JL, Gajiwala KS, Maffei M, Cohen SL, Chait BT, Robinowitz D et al. Weight-reducing effects of the plasmaprotein encoded by the obese gene. Science 1995269 543-546.

103 Campfield LA, Smith FJ, Guisez Y, Devos R \& Burn P. Recombinant mouse ob protein - evidence for a peripheral signal linking adiposity and central neural networks. Science $1995269546-549$.

104 Pelleymounter MA, Cullen MJ, Baker MB, Hecht R, Winters D, Boone $\mathrm{T}$ et al. Effects of the ob-gene product on body weight regulation in ob/ob mice. Science 1995269 540-543.

105 Muzzin P, Eisensmith RC, Copeland KC \& Woo SL. Correction of obesity and diabetes in genetically obese mice by leptin gene therapy. PNAS 199693 14804-14808.

106 Chen G, Koyoma K, Yuan X, Lee Y, Zhou YT, O’Doherty R et al. Disappearance of body fat in normal rats induced by adenovirus-mediated leptin gene therapy. PNAS 199693 14795-14799.

107 Shimabukuro M, Koyama K, Chen G, Wang MY, Trieu F, Lee Y et al. Direct antidiabetic effect of leptin through triglyceride depletion of tissue. PNAS 199794 4637-4641.

108 Morsy MA, Gu MC, Zhao JZ, Holder DJ, Rogers IT, Pouch WJ et al. Leptin gene therapy and daily protein administration: comparative study in the ob/ob mouse. Gene Therapy 19985 8-18.

109 Zhou Y-T, Wang Z-W, Higa M, Newgard CB \& Unger RH. Reversing adipocyte differentiation: implications for treatment of obesity. PNAS 199996 2391-2395.

110 Morsy MA, Gu MC, Motzel S, Zhao J, Lin J, Su Q et al. An adenoviral vector deleted for all viral coding sequences results in enhanced safety and extended expression of a leptin transgene. PNAS 199895 7866-7871.

111 Murphy JE, Zhou S, Giese K, Williams LT, Escobedo JA \& Dwarki VJ. Long-term correction of obesity and diabetes in genetically obese mice by single intramuscular injection of recombinant adeno-associated virus encoding mouse leptin. PNAS 199794 13921-13926.

112 Seroogy CM \& Fathman CG. The application of gene therapy in autoimmune diseases. Gene Therapy 2000 7 9-13.

113 Evans CH, Robbins PD, Ghivizzani SC, Herdon JH, Kang R, Bahnson $\mathrm{AB}$ et al. Clinical trial to assess the safety, feasibility, and efficacy of transferring potentially anti-arthritic cytokine gene to human joints with rheumatoid arthritis. Human Gene Therapy 19967 1261-1280. 
114 Bongioanni MR, Durelli L, Ferrero B, Imperiale D, Oggero A Verdun E et al. Systemic high-dose recombinant alpha-2a interferon therapy modulates lymphokine production in multiple sclerosis. Journal of Neurological Sciences 199336 1681-1690.

115 Moreland LW, Baumgartner SW, Schiff MH, Tindall EA, Fleischmann RM, Weaver AL et al. Treatment of rheumatoid arthritis with recombinant human tumor necrosis factor receptor (p75)-Fc fusion protein. New England Journal of Medicine $1997337141-147$.

116 Shaw MK, Lorens JB, Dhawan A, Dal Canto R, Tse HY, Tran AB et al. Local delivery of interleukin 4 by retrovirus-transduced $\mathrm{T}$ lymphocytes ameliorates experimental autoimmune encephalomyelitis. Journal of Experimental Medicine 1997185 1711-1714.

117 Mathisen PM, Yu M, Johnson JM, Drazba JA \& Tuohy VK. Treatment of experimental autoimmune encephalomyelitis with genetically modified memory $\mathrm{T}$ cells. Journal of Experimental Medicine 1997186 159-164.

118 Fisher GH, Rosenberg FJ, Straus SE, Dale JK, Middleton LA, Lin AY et al. Dominant interfering Fas gene mutations impair apoptosis in a human autoimmune lymphoproliferative syndrome. Cell 199581 935-946.

119 Rieux-Laucat F, Le Diest F, Hivroz C, Roberts IA, Debatin KM, Fisher A et al. Mutations in Fas associated with human lymphoproliferative syndrome and autoimmunity. Science 1995 268 1347-1349.

120 Batteux F, Tourneur L, Trebeden H, Charreire J \& Chiocchia G. Gene therapy of experimental autoimmune thyroiditis by in vivo administration of plasmid DNA coding for Fas ligand. Journal of Immunology 1999162 603-608.

121 Giordano C, Stassi G, De Maria R, Todaro M, Richiusa P \& Papoff G. Potential involvement of Fas and its ligand in the pathogenesis of Hashimoto's thyroiditis. Science 1997275 960-693.

122 Batteux F, Trebeden H, Charreire J \& Chiocchia G. Curative treatment of experimental autoimmune thyroiditis by in vivo administration of plasmid DNA coding for interleukin-10. European Journal of Immunology 199929 958-963.

123 Mignon-Godefroy K, Rott O, Brazillet MP \& Charreire J. Curative and protective effects of IL-10 in experimental autoimmune thyroiditis (EAT). Journal of Immunology 1995 $1546634-6643$.

124 Vile RG, Russell SJ \& Lemoine NR. Cancer gene therapy: hard lessons and new courses. Gene Therapy 20007 2-8.

125 James HA \& Gibson I. The therapeutic potential of ribozymes. Blood 199891 371-382.

126 Sullenger BA \& Chech TR. Ribozyme-mediated repair of defective mRNA by targeted trans-splicing. Nature 1994371 619-622.

127 Daughday WH. The possible autocrine/paracrine and endocrine roles of insulin-like growth factors of human tumors. Endocrinology $19901271-4$.

128 Neuenschwander S, Roberts CT Jr \& LeRoith D. Growth inhibition of MCF-7 breast cancer cells by stable expression of an insulin-like growth factor I receptor antisense ribonucleic acid. Endocrinology $19951364298-4303$.

129 Xu Z-D, Oey L, Subburaman M, Kawachi MH, Lee N-S, Rossi JJ et al. Hammerhead ribozyme-mediated cleavage of the human insulin-like growth factor-II ribonucleic acid in vitro and in prostate cancer cells. Endocrinology 1999140 2134-2144.

130 Chen S, Song CS, Lavrovsky Y, Bi B, Vellanoweth R, Chatterjee B et al. Catalytic cleavage of the androgen receptor messenger RNA and functional inhibition of androgen receptor activity by a hammerhead ribozyme. Molecular Endocrinology 199812 1558-1566.

131 Lavrovsky Y, Tyagi RK, Chen S, Song CS, Chatterjee B \& Roy AK. Ribozyme-mediated cleavage of the estrogen receptor messenger RNA and inhibition of receptor function in target cells. Molecular Endocrinology 199913 925-934.
132 Reinke M. Mutations in adrenocortical tumors. Hormone and Metabolic Research 199830 447-455.

133 Fagin JA, Matsuo K, Karmakar A, Chen DL, Tang SH \& Koeffler HP. High prevalence of mutations of the p53 gene in poorly differentiated carcinomas of the thyroid gland. Journal of Clinical Investigations 199391 1753-1760.

134 Nielsen LL \& Maneval DC. p53 tumor suppressor gene therapy for cancer. Cancer Gene Therapy 19985 52-63.

135 Fagin JA, Tang SH, Zeki K, Di Lauro R, Fusco A \& Gonsky R. Reexpression of thyroid peroxidase in a derivative of an undifferentiated thyroid carcinoma cell line by introduction of wild-type p53. Cancer Research 199656 765-771.

136 Moretti F, Farsetti A, Soddu S, Misiti S, Crescenzi M, Filetti S et al. p53 re-expression inhibits proliferation and restores differentiation of human thyroid anaplastic carcinoma cells. Oncogene $199714729-740$.

137 Blagosklonny MV, Giannakakou P, Wajtowicz M, Romanova LY, Ain KB, Bates SE et al. Effects of p53-expressing adenovirus on the chemosensitivity and differentiation of anaplastic thyroid cancer cells. Journal of Clinical Endocrinology and Metabolism $1998832516-2522$.

138 Narimatsu M, Nagayama Y, Akino K, Yasuda M, Yamamoto T, Yang T-T et al. Therapeutic usefulness of wild-type $p 53$ gene introduction in a p53-null anaplastic thyroid carcinoma cell line. Journal of Clinical Endocrinology and Metabolism $1998 \mathbf{8 3}$ 3668-3672.

139 Moretti F, Nanni S, Farsetti A, Narducci M, Crescenzi M, Giugliacci $S$ et al. Effects of exogenous p53 transduction in thyroid tumor cells with different p53 status. Journal of Clinical Endocrinology and Metabolism 200085 302-308.

$140 \mathrm{Hu}$ N, Gutsmann A, Herbert DC, Bradley A, Lee WH \& Lee EY. Heterozygous $R b-1^{\Delta 20 /+}$ mice are predisposed to tumors of the pituitary gland with nearly complete penetrance. Oncogene 1994 9 1021-1029.

141 Yamasaki L, Bronsin R, Williams BO, Dyson NJ, Harlow E \& Jacks T. Loss of E2F-1 reduces tumorigenesis and extends the lifespan of $\mathrm{Rb}^{+/-}$mice. Nature Genetics $199818360-364$.

142 Riley DJ, Nikitin AY \& Lee W-H. Adenovirus-mediated retinoblastoma gene therapy suppress spontaneous pituitary melanotroph tumors in $\mathrm{Rb}^{+/-}$mice. Nature Medicine 19962 1316-1321.

143 Nikitin AY, Juarez-Perez MI, Li S, Huang L \& Lee W-H. RBmediated suppression of spontaneous multiple neuroendocrine neoplasia and lung metastases in $\mathrm{Rb}^{+/-}$mice. PNAS 199996 3916-3921.

144 Woloschak M, Yu A, Xiao J \& Post KD. Frequent loss of the p16 ${ }^{\text {INK4a }}$ gene product in human pituitary tumors. Cancer Research 199656 2493-2496.

145 Fero ML, Rivkin M, Tasch M, Porter P, Carow CE, Firpo E et al. A syndrome of multiorgan hyperplasia with features of gigantism, tumorigenesis, and female sterility in p $27^{\mathrm{Kip} 1}$-deficient mice. Cell $199685733-744$

146 Kiyokawa H, kineman RD, Manova-Todorova KO, Soares VC, Hoffman ES, Ono $M$ et al. Enhanced growth of mice lacking the cyclin-dependent kinase inhibitor function of $\mathrm{p} 27^{\mathrm{Kip} 1}$. Cell $199685721-732$.

147 Nakayama K, Ishida N, Shirane M, Inomata A, Inoue T, Shishido $\mathrm{N}$ et al. Mice lacking p2 $7^{\mathrm{Kip} 1}$ display increased body size, multiple organ hyperplasia, retinal dysplasia, and pituitary tumors. Cell 199685 707-720.

148 Frost SJ, Simpson DJ, Clayton RN \& Farrel WE. Transfection of an inducible p16/CDKN2A construct mediates reversible growth inhibition and $\mathrm{G}_{1}$ arrest in the AtT20 pituitary tumor cell line. Molecular Endocrinology 199913 18011810 .

149 O'Reilly MS, Boehm T, Shing Y, Fukai N, Vasios G, Lane WS et al. Endostatin: an endogenous inhibitor of angiogenesis and tumor growth. Cell 199788 277-285.

150 Millauer B. Shawver LK, Plate KH, Risau W \& Ullrich A. Glioblastoma growth inhibited in vivo by a dominant-negative Flk-1 mutant. Nature 1994367 576-579. 
151 Lau KKW \& Bicknell R. Antiangiogenic gene therapy. Gene Therapy 19996 1793-1795.

152 Viglietto G, Maglione D, Rambaldi M, Cerutti J, Romano A, Trapasso F et al. Upregulation of vascular endothelial growth factor (VEGF) and downregulation of placenta growth factor (PIGF) associated with malignancy in human thyroid tumors and cell lines. Oncogene 199511 1569-1579.

153 Bunone G, Vigneri P, Mariani L, Butò S, Collini P, Pilotti S et al. Expression of angiogenesis stimulators and inhibitors in human thyroid tumors and correlation with clinical pathological features. American Journal of Pathology 1999155 1967-1976.

154 Klein M, Picard E, Vignaud JM, Marie B, Bresler L, Toussaint B et al. Vascular endothelial growth factor gene and protein: strong expression in thyroiditis and thyroid carcinoma. Journal of Endocrinology 1999161 41-49.

155 Ishiwata T, Iino Y, Takei H, Oyama T \& Morishita Y. Tumor angiogenesis as an independent prognostic indicator in human papillary thyroid carcinoma. Oncological Reports 1998 5 1343-1348.

156 Fontanini G, Vignati S, Pacini F, Pollina L \& Basolo F. Microvessel count: an indicator of poor outcome in medullary thyroid carcinoma but not in other types of thyroid carcinoma. Modern Pathology $19969636-641$.

157 Belletti B, Ferraro P, Arra C, Baldassarre G, Bruni P, Staibano S et al. Modulation of in vivo growth of thyroid tumor derived cell lines by sense and antisense vascular endothelial growth factor gene. Oncogene 199918 4860-4869.

158 Hama Y, Shimizu T, Hosaka S, Sugenoya A \& Usuda N. Therapeutic efficacy of the angiogenesis inhibitor O-(chloroacetyl-carbamoyl) fumagillol (TNP-470; AGM-1470) for human anaplastic thyroid carcinoma in nude mice. Experimental Toxicology and Pathology 199749 239-247.

159 Fan L \& Iseki S. Immunohistochemical localization of vascular endothelial growth factor in the endocrine glands of the rat. Archives of Histology and Cytology 199861 17-28.

160 Shifren JL, Mesiano S, Taylor RN, Ferrara N \& Jaffe RB. Corticotropin regulates vascular endothelial growth factor expression in human fetal adrenal cortical cells. Journal of Clinical Endocrinology and Metabolism 199883 1342-1347.

161 Sasano H, Ohashi Y, Suzuki T \& Nagura H. Vascularity in human adrenal cortex. Modern Pathology 199811 329-333.

162 Liu O, Djuricin G, Staren ED, Gattuso P, Gauld VE, Shen J et al. Tumor angiogenesis in pheochromocytomas and paragangliomas. Surgery $1996120938-942$.

163 Jugenburg M, Kovacs K, Stefaneanu L \& Scheithauer BW. Vasculature in nontumorous hypophyses, pituitary adenomas and carcinomas: a quantitative morphologic study. Endocrine Pathology 19956 115-124.

164 Turner HE, Nagy ZS, Gatter KC, Esiri MM, Harris AL \& Wass JAH. Angiogenesis in pituitary adenomas and the normal pituitary gland. Journal of Clinical Endocrinology and Metabolism 200085 1159-1162.

165 Schecter J, Goldsmith P, Wilson C \& Weimer R. Morphological evidence for the presence of arteries in human prolactinomas. Journal of Clinical Endocrinology and Metabolism $1988 \quad 67$ 713-719.

166 Gorczyca W \& Hardy J. Microadenomas of the human pituitary and their vascularization. Neurosurgery 198822 1-6.

167 Elias KA \& Weiner R. Direct arterial vascularisation of estrogeninduced prolactin-secreting anterior pituitary tumors. PNAS $1984814549-4553$.

168 Renner U, Pagotto U, Artz E \& Stalla GK. Autocrine and paracrine roles of polypeptide growth factors, cytokines and vasogenic substances in normal and tumorous pituitary function and growth: a review. European Journal of Endocrinology 1996135 515-532.

169 Jabbour HN, Boddy SC \& Lincoln GA. Flt-1 in the ovine pituitary gland: expression is independent of hypothalamic control. Molecular and Cellular Endocrinology 1997134 91-100.
170 Ferrara N, Schweigerer L, Neufeld G, Mitchell R \& Gospodarowicz D. Pituitary follicular cells produce basic fibroblast growth factor. PNAS 198784 5773-5777.

171 Gloddek J, Pagotto U, Paez Pereda M, Artz E, Stalla GK \& Renner U. Pituitary adenylate cyclase-activating polypeptide, interleukin-6 and glucocorticoids regulate the release of vascular endothelial growth factor in pituitary folliculostellate cells. Journal of Endocrinology 1999160 483-490.

172 Banerjee SK, Zoubine MN, Tran TM, Weston AP \& Campbell DR. Overexpression of vascular endothelial growth factor 164 and its co-receptor neuropilin-1 in estrogen-induced rat pituitary tumors and $\mathrm{GH} 3$ rat pituitary. International Journal of Oncology $200016253-260$.

173 Heaney AP, Horwitz GA, Wang Z, Singson R \& Melmed S. Early involvement of estrogen-induced pituitary tumor transforming gene and fibroblast growth factor expression in prolactinoma pathogenesis. Nature Medicine 19995 1317-1321.

174 Rigg A \& Sikora K. Genetic prodrug activation therapy. Molecular Medicine Today 19973 359-366.

175 Nishihara E, Nagayama Y, Mawatari F, Tanaka K, Namba H, Niwa $\mathrm{M}$ et al. Retrovirus-mediated herpes simplex virus thymidine kinase gene transduction renders human thyroid carcinoma cell lines sensitive to ganciclovir and radiation in vitro and in vivo. Endocrinology 1997138 4577-4583.

176 Braiden V, Nagayama Y, Iitaka M, Namba H, Niwa M \& Yamashita S. Retrovirus-mediated suicide gene/prodrug therapy targeting thyroid carcinoma using a thyroid-specific promoter. Endocrinology 1998130 3996-3999.

177 Takeda T, Yamazaki M, Minemura K, Ichikawa K, Miyamoto T, Suzuki S et al. Cell-specific gene therapy for thyroid carcinomas by adenovirus-mediated suicide genes driven by thyroglobulin promoter. Book of the Endocrine Society 81st Annual Meeting, 1999, P1-587, p 259.

178 Nagayama Y, Nishihara E, Iitaka M, Namba H, Yamashita S \& Niwa M. Enhanced efficacy of transcriptionally targeted suicide gene/prodrug therapy for thyroid carcinoma with the Cre-loxP system. Cancer Research 199959 3049-3052.

179 Minemura K, Minemura K \& DeGroot LJ. Tissue specific approach to gene therapy for medullary thyroid carcinoma reduces the side effects caused by the HSV-TK/GCV system in an experimental animal model. Abstract Book of the Endocrine Society 81st Annual Meeting 1999 P1-571 p 255.

180 Castro MG, Goya RG, Sosa YE, Rowe J, Larregina A, Morelli A et al. Expression of transgenes in normal and neoplastic anterior pituitary cells using recombinant adenoviruses: long term expression, cell cycle dependency, and effects on hormone secretin. Endocrinology 1997138 2184-2194.

181 Lee EJ, Anderson LM, Thimmapaya B \& Jameson JL. Targeted expression of toxic genes directed by pituitary hormone promoters: a potential strategy for adenovirus mediated gene therapy of pituitary tumors. Journal of Clinical Endocrinology and Metabolism 199984 786-794.

182 Neill JD, Musgrove LC, Wayne Duck L \& Sellers JC. High efficiency method for gene transfer in normal pituitary gonadotropes: Adenoviral-mediated expression of $\mathrm{G}$ protein-coupled receptor kinase 2 suppresses luteinizing hormone secretion. Endocrinology $19991402562-2569$.

183 Stone D, David A, Bolognani F, Lowestein PR \& Castro MG. Viral vectors for gene delivery and gene therapy within the endocrine system. Journal of Endocrinology 2000164 103-118.

184 Davis JRE, Lowenstein PR, McNeilly AS \& Castro MG. Gene therapy for pituitary tumors. Endocrine-Related Cancer 19996 475-481.

185 Castro MG. Gene therapy strategies for the treatment of pituitary tumors. Journal of Molecular Endocrinology 199922 9-18.

186 Windeatt S, Southgate TD, Dewey RA, Bolognani F, Perone MJ, Lorregina AT et al. Adenovirus-mediated herpes simplex virus type-1 thymidine kinase (HSV1-TK) gene therapy suppresses oestrogen-induced pituitary prolactinomas. Journal of Clinical Endocrinology and Metabolism 200085 1296-1305. 
187 Windeatt S, Perone MJ, Davis JR, Lowenstein PR \& Castro MG Development of a cell-type specific recombinant adenovirus for transgene expression in pituitary lactotrophic cells. Abstract Book of the Endocrine Society 81st Annual Meeting, 1999, P2-100, p302.

188 Castro MG, Windeatt S, Smith-Arica J \& Lowenstein PR. Celltype specific expression in the pituitary: physiology and gene therapy. Biochemical Society Transactions 199927 858-863.

189 Smith-Arica J, Stanley PJ, Windeatt S, Davis JRE, Smith J, Lowenstein PR et al. Pituitary specific and inducible gene expression from first generation adenoviral vectors in vitro: possibilities for gene therapy. Abstracts for the American Society for Gene Therapy 2nd Annual Meeting, 1999, 196a, no. 776

190 Skinner MM, Nass R, Lopes B, Laws ER \& Thorner MO. Growth hormone secretagogue receptor expression in human pituitary tumors. Journal of Clinical Endocrinology and Metabolism 1998 $834314-4320$.

191 de Keyzer Y, Rene P, Beldjord C, Lenne F \& Bertagna X Overexpression of vasopressin (V3) and corticotropin-releasing hormone receptor genes in corticotroph tumours. Clinical Endocrinology $199849475-482$.

192 Goya RG, Rowe J, Sosa YE, Tomasec P, Lowenstein PR \& Castro MG. Use of recombinant herpes simplex virus type 1 vectors for gene transfer into tumor and normal anterior pituitary cells. Molecular and Cellular Endocrinology 1998139 199-207.

193 Tomasec P, Preston CM, Linton EA, Ahmed I, Lowenstein PR \& Castro MG. Generation of a recombinant herpes simplex virus type 1 expressing the rat corticotropin-releasing hormone precursor: endoproteolytic processing, intracellular targeting and biological activity. Neuroendocrinology 199970 439-450.

194 Chuman Y, Zhan Z \& Fojo T. Construction of gene therapy vectors targeting adrenocortical cells: enhancement of activity and specificity with agents modulating the cyclic adenosine $3^{\prime}, 5^{\prime}$-monophsphate pathway Journal of Clinical Endocrinology and Metabolism 200085 253-262.

195 Gicquel C, Bertagna X, Schneid H, Francillard-Leblond M, Luton JP, Girard F et al. Rearrangements at 11p15 locus and overexpression of insulin like growth factor-II gene in sporadic adrenocortical tumors. Journal of Clinical Endocrinology and Metabolism 199478 1444-1453.

196 Takano T, Matsuzuka F, Miyauchi A, Yokozawa T, Liu G, Morita S et al. Restricted expression of oncofetal fibronectin mRNA in thyroid papillary and anaplastic carcinoma: an in situ hybridization study. British Journal of Cancer 199878 221-224.

197 Mandell RB, Mandell LZ \& Link CJ Jr. Radioisotope concentrator gene therapy using the sodium/iodide symporter gene. Cancer Research $199959661-668$.

198 Pardoll D \& Nabel GJ. Cancer immunotherapy. In The Development of Human Gene Therapy, pp 427-457. Ed. T Friedmann. Cold Spring Harbor, New York: Cold Spring Harbour Laboratory Press 1999.
199 Tang DC, De Vit M \& Johnston SA. Genetic immunization is a simple method for eliciting an immune response. Nature 1992 356 152-154.

200 Colaco CASL. Why are dendritic cells central to cancer immunotherapy? Molecular Medicine Today 19995 14-17.

201 Zhang R, Straus FH \& DeGroot LJ. Effective genetic therapy of established medullary thyroid carcinoma with murine interleukin-2: dissemination and cytotoxicity studies in a rat tumor model. Endocrinology 1999140 2152-2158.

202 Zhang R, Baunoch D \& De Groot LJ. Genetic immunotherapy for medullary thyroid carcinoma: destruction of tumors in mice by in vivo delivery of adenoviral vector transducing the murine interleukin-2 gene. Thyroid 19988 1137-1146.

203 Zhang R, Minemura K \& De Groot LJ. Immunotherapy for medullary thyroid carcinoma by replication-defective adenovirus transducing murine interleukin-2. Endocrinology 1998 $139601-608$.

204 Castleden SA, Chong H, Garcia-Ribas I, Melcher AA, Hutchinson G, Roberts B et al. A family of bicistronic vectors to enhance both local and systemic antitumor effects of HSV-TK or cytokine expression in a murine melanoma model. Human Gene Therapy 19978 1919-1934.

205 Pizzato M, Franchin E, Calvi P, Boschetto R, Colombo M, Ferrini S et al. Production and characterization of a bicistronic Moloneybased vector expressing human interleukin-2 and herpes simplex virus thymidine kinase for gene therapy of cancer. Gene Therapy 19985 1003-1007.

206 Palù G, Pizzato M, Bonaguro R \& Colombo F. Gene therapy of glioblastoma multiforme with a bicistronic retroviral vector expressing human IL-2 and HSV-TK. Methods in Molecular Medicine, Vol. 35: Gene Therapy: Methods and Protocols. Eds W Walther and U Stein. Totowa, NJ: Humana Press.

207 Palù G, Cavaggioni A, Calvi P, Franchin E, Pizzato M, Boschetto R et al. Gene therapy of glioblastoma multiforme via combined expression of suicide and cytokine genes: a pilot study in humans. Gene Therapy 19996 330-337.

208 Palù G, Barzon L \& Bonaguro R. Glioblastoma multiforme: molecular biology and new perspectives for therapy. Gene Therapy and Molecular Biology 19993 133-148.

209 Barzon L, Bonaguro R, Benetti L, Palù G \& Boscaro M. Retroviral vector for gene therapy of thyroid tumors via tissue-specific expression of suicide and immunomodulating genes. Abstract Book of the Endocrine Society 81st Annual Meeting, 1999, $\mathrm{P} 2-723, \mathrm{p} 433$.

210 Soler MN, Milhaud G, Lekmine F, Treilhou-Lahille F, Klatzmann D \& Lausson S. Treatment of medullary thyroid carcinoma by combined expression of suicide and interleukin-2 genes. Cancer Immunology and Immunotherapy 199948 91-99.

Received 11 April 2000

Accepted 9 June 2000 